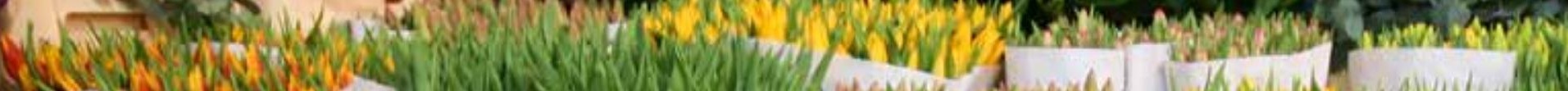

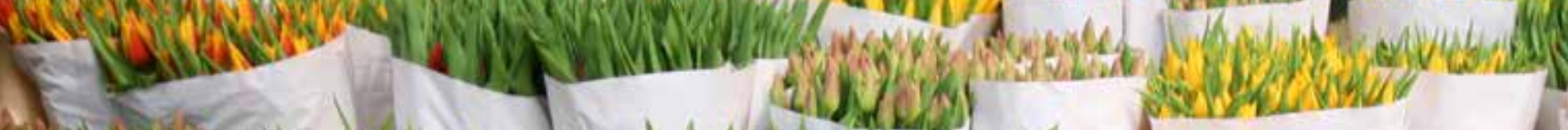

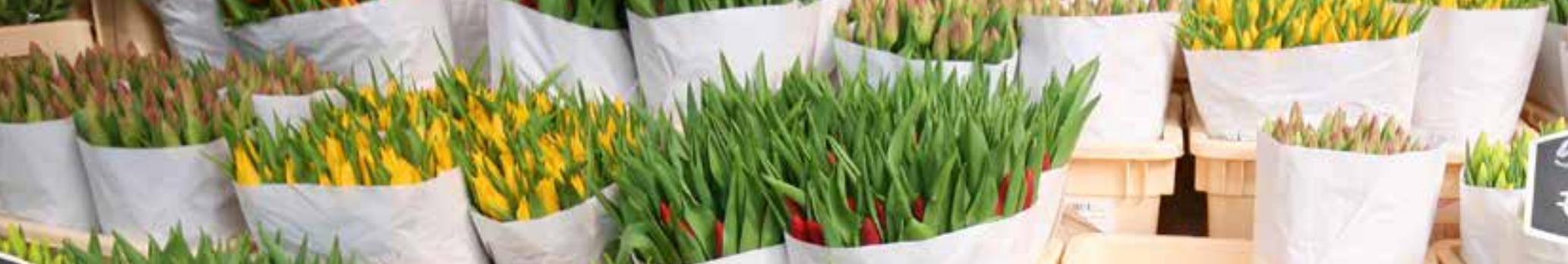
andiving

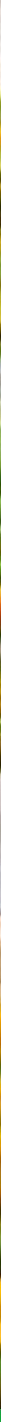

Doorrekening effecten van btw-verhoging op sierteeltproducten in Nederland en EU

Update situatie 2021

Michiel van Galen en Gerben Jukema

WAGENINGEN
$\square$ UNIVERSITY \& RESEARCH 



\section{Doorrekening effecten van btw-verhoging op sierteeltproducten in Nederland en EU}

Update situatie 2021

Michiel van Galen en Gerben Jukema

Dit onderzoek is uitgevoerd door Wageningen Economic Research in opdracht van en gefinancierd door de Vereniging van Bloemenveilingen in Nederland.

Wageningen Economic Research

Wageningen, maart 2021

RAPPORT

2021-043

ISBN 978-94-6395-762-5 
Van Galen, M.A., G. Jukema, 2021. Doorrekening effecten van btw-verhoging op sierteeltproducten in Nederland en EU; Update situatie 2021. Wageningen, Wageningen Economic Research, Rapport 2021-043. 30 blz.; 2 fig.; 12 tab.; 7 ref.

Sierteeltproducten worden in Nederland in een verlaagd btw-tarief belast ( $9 \%$ in plaats van $21 \%$ ) en in twaalf andere EU-landen ook. Een verhoging van de btw heeft negatieve gevolgen voor omzet en werkgelegenheid in de keten. Deze doorrekening laat zien dat een btw-verhoging in Nederland leidt tot een verlies van ongeveer 170 miljoen euro omzet in de sierteeltketen tegen groothandelsprijzen $(-1,6 \%)$. Als ook in andere EU landen de btw verhoogd wordt, dan heeft dat vooral effect op de export van Nederland en daarmee ook op de primaire productie. Het extra verlies aan omzet van de sierteeltketen is (tegen groothandelsprijzen) berekend op 620 miljoen euro (-6\%). De langetermijneffecten op de Nederlandse btw-inkomsten zijn berekend op 226 en 229 miljoen euro stijging afhankelijk van of alleen Nederland de btw verhoogt of ook de andere EU-landen die een verlaagd tarief hanteren. Op korte termijn is het effect op de overheidsfinanciën minder groot door een stijging van de kosten van de sociale zekerheid en daling van de inkomstenbelasting.

Ornamentals are taxed at a reduced VAT rate in the Netherlands ( $9 \%$ instead of $21 \%$ ) and twelve other EU countries. An increase of VAT on ornamentals would have a negative impact on turnover and employment in the chain. This calculation shows that the effects of a VAT increase in the Netherlands leads to more than 170 million euros in loss of turnover in the Dutch ornamentals chain valued at wholesaler prices $(-1.6 \%)$. If in other EU countries VAT is increased as well, there will be an effect on Dutch exports and consequently also the primary sector. The extra loss of turnover at wholesaler prices is estimated at 620 million euro (-6\%). The long-term effects on VAT income of the Dutch government are calculated to increase by 226 million euros and 229 million euros, depending on whether only the Netherlands increases the VAT or also the other EU countries that apply a reduced rate. In the short term the effect on public finances is less significant due to an increase in the costs of social security and a decrease in income tax.

Trefwoorden: sierteelt, btw-tarief, werkgelegenheid, export

Dit rapport is gratis te downloaden op https://doi.org/10.18174/544239 of op www.wur.nl/economicresearch (onder Wageningen Economic Research publicaties).

(C) 2021 Wageningen Economic Research

Postbus 29703, 2502 LS Den Haag, T 07033583 30, E communications.ssg@wur.nl, www. wur.nl/economic-research. Wageningen Economic Research is onderdeel van Wageningen University \& Research.

\section{(cc) BY-NC}

Dit werk valt onder een Creative Commons Naamsvermelding-Niet Commercieel 4.0 Internationaallicentie.

(C) Wageningen Economic Research, onderdeel van Stichting Wageningen Research, 2021 De gebruiker mag het werk kopiëren, verspreiden en doorgeven en afgeleide werken maken. Materiaal van derden waarvan in het werk gebruik is gemaakt en waarop intellectuele eigendomsrechten berusten, mogen niet zonder voorafgaande toestemming van derden gebruikt worden. De gebruiker dient bij het werk de door de maker of de licentiegever aangegeven naam te vermelden, maar niet zodanig dat de indruk gewekt wordt dat zij daarmee instemmen met het werk van de gebruiker of het gebruik van het werk. De gebruiker mag het werk niet voor commerciële doeleinden gebruiken.

Wageningen Economic Research aanvaardt geen aansprakelijkheid voor eventuele schade voortvloeiend uit het gebruik van de resultaten van dit onderzoek of de toepassing van de adviezen.

Wageningen Economic Research is ISO 9001:2015 gecertificeerd.

Wageningen Economic Research Rapport 2021-043 | Projectcode 2282100413

Foto omslag: Shutterstock 


\section{Inhoud}

Woord vooraf $\quad 5$

$\begin{array}{ll}\text { Samenvatting } & 6\end{array}$

$\begin{array}{lll}\text { S.1 Belangrijkste uitkomsten } & 6\end{array}$

$\begin{array}{ll}\text { S.2 Methode } & 7\end{array}$

$\begin{array}{ll}\text { Summary } & 8\end{array}$

S.1 Primary Findings $\quad 8$

$\begin{array}{ll}\text { S.2 Method } & 9\end{array}$

$\begin{array}{lr}1 & \text { Inleiding }\end{array}$

$2 \quad$ Nederland en de Europese sierteelt $\quad 12$

\begin{tabular}{l|r}
3 & Btw op sierteeltproducten
\end{tabular}

$\begin{array}{llr}4 & \text { Methode } & 18\end{array}$

$\begin{array}{lll}4.1 & \text { Inleiding } & 18\end{array}$

4.2 Drie scenario's $\quad 18$

$\begin{array}{llr}4.3 & \text { Hortus-model } & 18\end{array}$

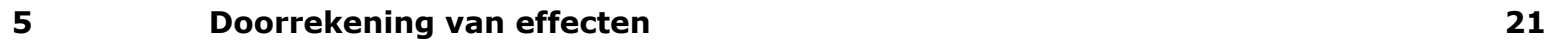

$\begin{array}{lll}5.1 & \text { Inleiding } & 21\end{array}$

5.2 Scenario 1: Verhoging btw in Nederland $\quad 21$

5.3 Scenario 2: Verhoging btw in andere EU-landen dan Nederland 22

5.4 Scenario 3: Verhoging btw in hele EU 23

$\begin{array}{lll}5.5 & \text { Effecten op de overheidsfinanciën in Nederland } & 24\end{array}$

6

$\begin{array}{ll}\text { Conclusies } & \mathbf{2 7}\end{array}$

$\begin{array}{ll}\text { Literatuur en websites } & 29\end{array}$ 



\section{Woord vooraf}

In Nederland en in twaalf andere EU-landen wordt in plaats van het algemene btw-tarief een verlaagd btw-tarief toegepast op sierteeltproducten. De Nederlandse regering heeft in het verleden al enkele malen een verhoging van de btw op sierteeltproducten overwogen. Een dergelijke belastingherziening heeft tot doel het stelsel te vereenvoudigen en de belastinggrondslag te verbeteren. In dat kader worden de btw-regelingen voor diensten en producten, zoals boeken maar ook sierteeltproducten, heroverwogen. Op sierteeltproducten is al sinds 1975 het lage btw-tarief van toepassing in plaats van het algemene tarief. Ook is het niveau van het lage btw-tarief in Nederland in 2019 door kabinet Rutte III verhoogd van $6 \%$ naar $9 \%$.

In opdracht van de Vereniging van Bloemenveilingen in Nederland (VBN) heeft Wageningen Economic Research de betekenis van de btw-regeling voor omzet en werkgelegenheid in de sierteeltketen in kaart gebracht voor drie scenario's: een waarin Nederland unilateraal overgaat tot toepassing van het algemene btw-tarief, een scenario waarin alle andere lidstaten van de Europese Unie het algemene btw-tarief toepassen maar Nederland niet, en een scenario waarin alle landen inclusief Nederland die nu het verlaagde tarief toepassen het algemene tarief gaan hanteren. Deze resultaten zijn aangevuld met een analyse van de impact op de overheidsinkomsten. De studie is een actualisering van de analyses die in 2010 voor het Productschap Tuinbouw is uitgevoerd en van de analyses die in 2007 en 2014 voor het ministerie van LNV en in 2015 voor de VBN zijn uitgevoerd.

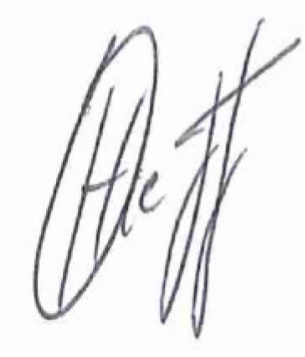

Ir. O. (Olaf) Hietbrink

Business Unit Manager Wageningen Economic Research Wageningen University \& Research

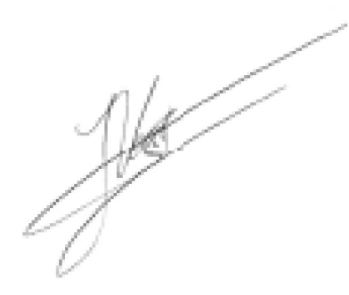

Prof.dr.ir. J.G.A.J. (Jack) van der Vorst Algemeen Directeur Social Sciences Group (SSG) Wageningen University \& Research 


\section{Samenvatting}

\section{S.1 Belangrijkste uitkomsten}

In dit onderzoek is doorgerekend wat de effecten van een verhoging van de btw op sierteeltproducten betekent voor de omzet en werkgelegenheid in Nederland en de EU-27 en het Verenigd Koninkrijk. In Nederland en in twaalf andere EU-landen worden sierteeltproducten in een verlaagd btw-tarief belast; in Nederland is dat $9 \%$ in plaats van $21 \%$. Als zou worden besloten om de btw op sierteeltproducten te verhogen, dan heeft dat negatieve gevolgen voor de omzet en werkgelegenheid in de keten. Er zijn drie scenario's bekeken:

1. een unilaterale verhoging van de btw op sierteeltproducten in Nederland, i.e. toepassing van het algemene tarief van $21 \%$ in plaats van het verlaagde tarief van $9 \%$;

2. een verhoging van de btw in alle andere EU-lidstaten die momenteel het verlaagde tarief hanteren;

3. een verhoging van de btw in zowel Nederland als de andere EU-landen met een verlaagd tarief.

Deze doorrekening laat zien dat een btw verhoging in Nederland via vraaguitval in Nederland kan leiden tot een omzetverlies van 420 miljoen euro (-13\%) op detailhandelsniveau, wat zich vertaalt in een verlies van 80 miljoen euro in de teelt van sierteeltgewassen in Nederland $(-1,3 \%)$. Op groothandelsniveau is dat een verlies van ongeveer 170 miljoen euro $(-1,6 \%)$ (zie scenario 1$)$. Als in andere EU landen waar nu het verlaagde tarief wordt gehanteerd de btw wordt verhoogd dan is het additionele effect op de Nederlandse sierteeltketen ingeschat op ongeveer 620 miljoen euro tegen groothandelsprijzen (-6\%) (zie scenario 2). Bij een btw-verhoging in Nederland en in de andere EUlanden verliest de sierteeltketen naar schatting ongeveer 780 miljoen euro omzet tegen groothandelsprijzen (-7\%) (zie scenario 3).

\section{Scenario 1}

In scenario 1, met alleen een btw verhoging in Nederland, daalt de consumentenvraag naar sierteeltproducten in Nederland met 420 miljoen euro (-13\%). De omzet van de groothandel daalt met 170 miljoen euro $(-1,6 \%)$ en de productie met 80 miljoen euro $(-1,3 \%)$. Er gaan 2.830 voltijdsbanen in de Nederlandse sierteeltketen verloren $(-3,9 \%)$.

\section{Scenario 2}

In scenario 2 wanneer in de twaalf andere EU-landen buiten Nederland het tarief wordt verhoogd, heeft dat alsnog gevolgen voor Nederland. De omzet in de Nederlandse detailhandel wordt dan nauwelijks beïnvloed, maar het verlies aan omzet in de (exporterende) groothandel en de productie is respectievelijk 620 miljoen euro (-6\%) en 350 miljoen euro (-6\%). Er gaan in dit scenario 3.190 voltijdsbanen verloren in Nederland. In de hele EU-27 levert dit scenario een verlies van 4,7 miljard euro aan detailhandelsomzet op (-8\%), en een daling van respectievelijk 2,8 miljard $(-7 \%)$ en 1,3 miljard euro $(-7 \%)$ van de groothandelsomzet en primaire productie. Het banenverlies is berekend op 53.700 voltijdsbanen op.

\section{Scenario 3}

In scenario 3 als in Nederland en de andere twaalf landen het tarief wordt verhoogd, wordt het omzetverlies in de detailhandel van de EU-27 en het Verenigd koninkrijk in totaal geschat op 5,1 miljard euro (-9\%). Dat vertaalt zich in een verlies van omzet van respectievelijk 3 miljard euro $(-8 \%)$ en 1,4 miljard euro (-8\%) op groothandelsniveau en in de teelt in de EU-27 en het Verenigd koninkrijk samen. In dit scenario zijn de effecten voor Nederland ook het grootst: 400 miljoen euro in de detailhandel $(-12 \%), 780$ miljoen euro in de groothandel $(-7 \%)$, en 430 miljoen euro in de primaire sector $(-7 \%)$. In termen van werkgelegenheid zijn de effecten in scenario 3 berekend op 6 duizend voltijdsbanen $(-9 \%)$ in de Nederlandse sierteeltketen, waarvan $2.890(-7 \%)$ in de primaire sector, $1.120(-7 \%)$ in de groothandel en $1.990(-15 \%)$ in de detailhandel. 


\section{Effect op de overheidsfinanciën in Nederland}

De effecten op de overheidsinkomsten in Nederland zijn berekend op basis van het verlies aan werkgelegenheid en omzet. In scenario 1 blijft van een initieel verwachte opbrengst van 360 miljoen euro op korte termijn 159 miljoen euro per jaar over, en 226 miljoen euro op langere termijn. In scenario 3 is dat 73 miljoen euro en 229 miljoen euro respectievelijk. In scenario 2 is het effect voor de btw-opbrengsten nihil omdat in Nederland de btw niet wordt aangepast. Wel zal door vraaguitval in het buitenland en verlies aan werkgelegenheid op korte termijn een negatief effect op de overheidsfinanciën optreden. Dat totale negatieve effect is geschat op 88 miljoen euro.

\section{S.2 Methode}

Deze doorrekening is gemaakt met het door Wageningen Economic Research ontwikkeld partieel evenwichtsmodel: Hortus. In Hortus worden productie, internationale handel en consumptie van tuinbouwproducten in de EU-landen en de rest van de wereld aan elkaar gerelateerd met geneste vraag- en aanbodvergelijkingen en vraag- en aanbodsubstitutie-elasticiteiten. De data voor het model worden zoveel mogelijk uit gevalideerde statistische bronnen gehaald. Voor de sierteeltsector zijn bovendien prijselasticiteiten in het model opgenomen die de vraag naar sierteeltproducten beïnvloeden als de prijzen veranderen. Voor deze update van het model zijn prijselasticiteiten gehanteerd die door onderzoeksbureau GfK in een parallel project zijn berekend. Het model berekent op basis van gegevens over productie, handel en consumptie en onder bepaalde aannames zoals bovengenoemde prijselasticiteiten en substitutie elasticiteiten, een nieuw evenwicht na een prijsschok als gevolg van de btw-verandering. De uitkomsten zijn procentuele veranderingen ten opzichte van de initiële situatie. De gevolgen voor de werkgelegenheid zijn vervolgens buiten het model berekend met behulp van gegevens over omzet per fte. De effecten op de overheidsfinanciën zijn vervolgens berekend op basis van gegevens over bruto lonen, sociale premies en belastingen. 


\section{Summary}

\section{S.1 Primary Findings}

This study evaluates the effects on turnover and employment in the Netherlands, the EU 27, and the United Kingdom of a potential increase in the VAT rate on ornamentals. Ornamentals are taxed at a reduced VAT rate in the Netherlands ( $9 \%$ instead of $21 \%$ ) and in 12 other EU countries. A decision to increase VAT on ornamentals would have a negative effect on turnover and employment in the chain. Three scenarios were considered:

1. a unilateral increase in the VAT rate on ornamentals in the Netherlands, implying the application of the general VAT rate of $21 \%$ instead of the reduced rate of $9 \%$;

2. an increase in VAT in all other EU member states that currently apply the reduced rate;

3. an increase in VAT in both the Netherlands and the other EU member states that currently apply the reduced rate.

This evaluation reveals that a VAT increase in the Netherlands could lead through a drop in demand to a loss in turnover of 420 million euros $(-13 \%)$ at retail level in the Netherlands, which in turn implies a loss of 80 million euros in the cultivation of ornamental crops in the Netherlands ( $-1.3 \%)$. At wholesale level, this is a loss of approximately 170 million euros euro $(-1.6 \%)$ (see Scenario 1 ). If the VAT rate is increased in other EU countries where the reduced rate is currently applied, the additional effect on the Dutch ornamentals chain is estimated at approximately 620 million euros at wholesale prices $(-6 \%)$ (see Scenario 2). Given a VAT increase in the Netherlands and in the other EU countries, the ornamentals chain will lose an estimated 780 million euros in turnover at wholesale prices (-7\%) (see Scenario 3).

\section{Scenario 1}

Scenario 1, with a VAT increase in the Netherlands only, leads to a drop in consumer demand for ornamentals in the Netherlands by 420 million euros $(-13 \%)$. The wholesale turnover falls by 170 million euros $(-1.6 \%)$ and production by 80 million euros $(-1.3 \%)$. Some 2,830 full-time jobs will be lost in the Netherlands $(-3.9 \%)$.

\section{Scenario 2}

In Scenario 2, where the rate is increased in the $12 \mathrm{EU}$ countries other than the Netherlands with a reduced rate, this nevertheless has consequences for the Netherlands. Turnover in the Dutch retail trade is then scarcely affected, but the loss in turnover in the (exporting) wholesale sector and in production is respectively 620 million euros (-6\%) and 350 million euros (-6\%). In this scenario, 3,190 full-time jobs are lost in the Netherlands. Across the entire EU 27, this scenario results in a loss of 4.7 billion euros in retail turnover $(-8 \%)$, and a fall of respectively of 2.8 billion $(-7 \%)$ and 1.3 billion euros $(-7 \%)$ in wholesale turnover and in primary production. Job losses are estimated at 53,700 full-time jobs.

\section{Scenario 3}

In Scenario 3, where the rate is increased in the Netherlands and the 12 other countries, the loss of turnover in retail sales in the EU 27 and the United Kingdom is estimated at a total of 5.1 billion euros $(-9 \%)$. This implies a loss in turnover of respectively 3 billion euros $(-8 \%)$ and 1.4 billion euros $(-8 \%)$ at wholesale level and at cultivation level in the EU 27 and the United Kingdom taken together. The effects for the Netherlands are also greatest in this scenario: 400 million euros in the retail trade $(-12 \%), 780$ million euros in wholesale $(-7 \%)$, and 430 million euros in the primary sector $(-7 \%)$. In terms of employment, the effects in Scenario 3 amount to a loss of 6,000 full-time jobs (-9\%) in the Dutch ornamentals chain, of which $2,890(-7 \%)$ in the primary sector, $1,120(-7 \%)$ in the wholesale sector, and $1,990(-15 \%)$ in retail. 


\section{Effect on op de public finances in the Netherlands}

The effects on public finances in the Netherlands have been calculated based on the loss in employment and in turnover. In Scenario 1, from an initially expected turnover of 360 million euros, 159 million euros per year remains in the short term, and 226 million euros in the longer term. In Scenario 3 this is 73 million euros and 229 million euros respectively. In Scenario 2, the effect on VAT revenue is nil because the VAT is not adjusted in the Netherlands. However, a drop in demand abroad and loss of employment will have a negative effect on public finances in the short term. That total negative effect has been estimated at 88 million euros.

\section{S.2 Method}

This calculation was made using a partial equilibrium model developed by Wageningen Economic Research: Hortus. The model relates production, international trade and consumption of horticultural products in the EU countries and the rest of the world through nested supply and demand equations, and supply and demand substitution elasticities. The model data are as much as possible obtained from validated statistical databases. For the ornamentals sector, price elasticities have also been included in the model that influence the demand for ornamental products when prices change. For this update, newly calculated price elasticities are used as calculated by GfK in a parallel project. Based on production, trade and consumption data and under certain assumptions like those on the mentioned price elasticities and substitution elasticities, the model calculates a new equilibrium after a price shock as a result of the VAT change. The results are percentage changes with respect to the initial situation. The consequences for employment were calculated outside of the model, using data on production value per FTE. The effects on public finances were then calculated on the basis of data on gross wages, social contributions and taxes. 


\section{$1 \quad$ Inleiding}

De sierteeltsector is een belangrijke economische sector voor Nederland met een productiewaarde van ongeveer 6 miljard euro en een totale exportwaarde van ruim 9 miljard euro in 2019. ${ }^{1}$ Naar schatting $80-85 \%$ van de in Nederland geproduceerde sierteeltproducten wordt geëxporteerd. Het gaat om snijbloemen, kamerplanten en balkonplanten, perkplanten, bloembollen en boomkwekerijgewassen en vaste planten. De belangrijkste exportbestemmingen liggen in de landen om Nederland heen en zijn Duitsland, Frankrijk, Engeland, België en Italië.

Sinds 1975 geldt voor alle sierteeltproducten in Nederland het verlaagde btw-tarief. De regeling is op initiatief van de Tweede Kamer ingesteld om sierteeltproducten betaalbaar te maken voor lage inkomensgroepen en om de omzet en werkgelegenheid in de tuinbouw te stimuleren. ${ }^{2}$ In de afgelopen decennia is het verlaagde btw-tarief op sierteeltproducten verschillende keren heroverwogen, meestal in tijden van economische recessie wanneer het rijk bezuinigingen overweegt. Ook is in 2019 door het kabinet Rutte III het verlaagde btw-tarief verhoogd van 6 naar $9 \%$.

In 2007 heeft de rijksoverheid de btw-regeling voor sierteeltproducten geëvalueerd. Wageningen Economic Research heeft een analyse uitgevoerd naar de effecten van de regeling op de consumentenbestedingen en de werkgelegenheid (Bunte et al., 2007). Het onderzoek kwam tot de conclusie dat de regeling effectief is, wat wil zeggen dat de gestelde doelen gerealiseerd worden. Mede naar aanleiding van deze analyse heeft de overheid in 2007 besloten de btw-regeling te continueren. De doorrekening in dit rapport is een update van de analyses uitgevoerd in 2007, 2010, en 2015 ('De eerdere studies': Bunte en Kuiper, 2008; Bunte en Van der Poel, 2010; Bunte en Van Galen, 2015).

Dit rapport presenteert de verwachte effecten van een verandering in het btw-tarief op de omzet en werkgelegenheid in de Europese productie, groothandel en detailhandel in sierteeltproducten. Hierbij wordt gebruikgemaakt van het vraag- en aanbodmodel voor tuinbouwproducten van Wageningen Economic Research: Hortus (Bunte en Van Galen, 2005). De analyse is alleen van toepassing op de sierteeltketen. Met effecten van een eventuele verhoging van het btw-tarief in andere sectoren hebben wij geen rekening gehouden.

Er worden drie scenario's doorgerekend: (1) een unilaterale verhoging van de btw op sierteeltproducten in Nederland, i.e. toepassing van het algemene tarief van $21 \%$ in plaats van het verlaagde tarief van $9 \%$; (2) een verhoging van de btw in de twaalf andere EU-lidstaten die momenteel het verlaagde tarief hanteren; (3) een verhoging van de btw in zowel Nederland als de andere EU-landen met een verlaagd tarief. De doorrekening betreft de effecten op omzet en werkgelegenheid in de sierteeltsector en -keten. De resultaten betreffen de effecten op Nederland voor scenario 1, en op de EU-27 en het Verenigd Koninkrijk voor scenario 2 en 3. Daarnaast wordt het effect op de Nederlandse overheidsfinanciën bekeken.

Op dit moment wordt het verlaagde tarief voor sierteeltproducten toegepast in 13 EU-lidstaten. Deze lidstaten vertegenwoordigen in 2019 ongeveer 85\% van de sierteeltproductiewaarde in de EU-27 en het Verenigd Koninkrijk samen, en ongeveer $75 \%$ van de consumptiewaarde. ${ }^{3}$ Als in deze lidstaten het algemene btw-tarief op sierteeltproducten zou worden toegepast, zullen de consumentenprijzen in deze landen stijgen. Als gevolg hiervan daalt de consumptie van sierteeltproducten. Dit resulteert in een daling van de netto-omzet, de handel tussen landen en de werkgelegenheid in de detail- en groothandel en de primaire productie in de sierteeltketen. Als alleen in Nederland de btw wordt verhoogd (scenario 1 ) dan heeft dat vooral effect op de consumentenvraag en detailhandelsomzet in

\footnotetext{
1 Bron: CBS. Deze cijfers zijn exclusief uitgangsmateriaal, champignonbroed. Inclusief uitgangsmateriaal gaat het om een totaal van 6,9 miljard euro productiewaarde en 9,5 miljard euro exportwaarde.

2 Amendement Tolman, TK 1974-1975, 13104 nr. 9. Het verlaagde btw-tarief mag in de EU worden toegepast op sierteeltproducten op basis van EU-richtlijn 2006/112/EG artikel 122.

3 Op basis van verschillende bronnen, voornamelijk van Eurostat en schattingen van Wageningen Economic Research.
} 
Nederland. De effect op de groothandel en de primaire productie worden dan derhalve veroorzaakt door de vraaguitval in Nederland. Als ook in andere landen de btw verhoogd wordt, dan komt het effect daarvan vooral tot uitdrukking in een daling van de exportomzet en de daarmee samenhangende daling van de productie in Nederland. Om een inschatting te kunnen maken van het totale effect op de omzet in de keten in Nederland kan gekeken worden naar het effect op de omzet op groothandelsniveau waarin zowel het effect op de binnenlandse vraag als de exportvraag tot uitdrukking komen. Immers, omzet op verschillende niveaus in de keten kan niet zondermeer bij elkaar worden geteld. 


\section{$2 \quad$ Nederland en de Europese sierteelt}

De Nederlandse sierteeltketen is zowel in Europa als wereldwijd belangrijk. In Nederland alleen al gaat het om een productiewaarde van bijna 6 miljard euro (exclusief uitgangsmateriaal, champignonbroed) (tabel 2.1). Dat is $33 \%$ van de Europese productie. Nederland speelt ook een centrale rol in de sierteelthandel in Europa. De exportwaarde van snijbloemen, potplanten, bollen en boomkwekerijproducten uit Nederland steeg tussen 2012 en 2020 van 7 miljard euro naar ruim 9 miljard euro (figuur 2.1). Nederland importeerde in 2019 voor ongeveer 2,2 miljard euro aan sierteeltproducten, waarvan 1,2 miljard euro van buiten de EU. Daarmee is Nederland ook een belangrijk doorvoerland. In het totaal van de in Nederland op de markt gekomen sierteeltproducten heeft import een aandeel (in waarde) van ongeveer een kwart. In totaal importeerde de EU voor 1,8 miljard euro van buiten de EU. Daarmee heeft Nederland een aandeel van ongeveer twee derde in de EU-import vanuit derde landen. (figuur 2.2).

Tabel 2.1 Productiewaarde in de sierteeltsector in Nederland en de EU-27 plus het Verenigd Koninkrijk, in miljoen euro, in 2019

$\begin{array}{lrr} & \text { Nederland } & \text { EU en Verenigd } \\ \text { Koninkrijk }\end{array}$

a) kamerplanten en balkonplanten; b) voor Nederland is de productie van potplanten in Eurostat en AIPH jaarboek bij nursery plants geteld; dat is hier gecorrigeerd. Uitgangsmateriaal voor de sierteelt is in de productiewaarde voor Nederland niet meegenomen. Bron: CBS, Eurostat, AIPH, en berekeningen Wageningen Economic Research.

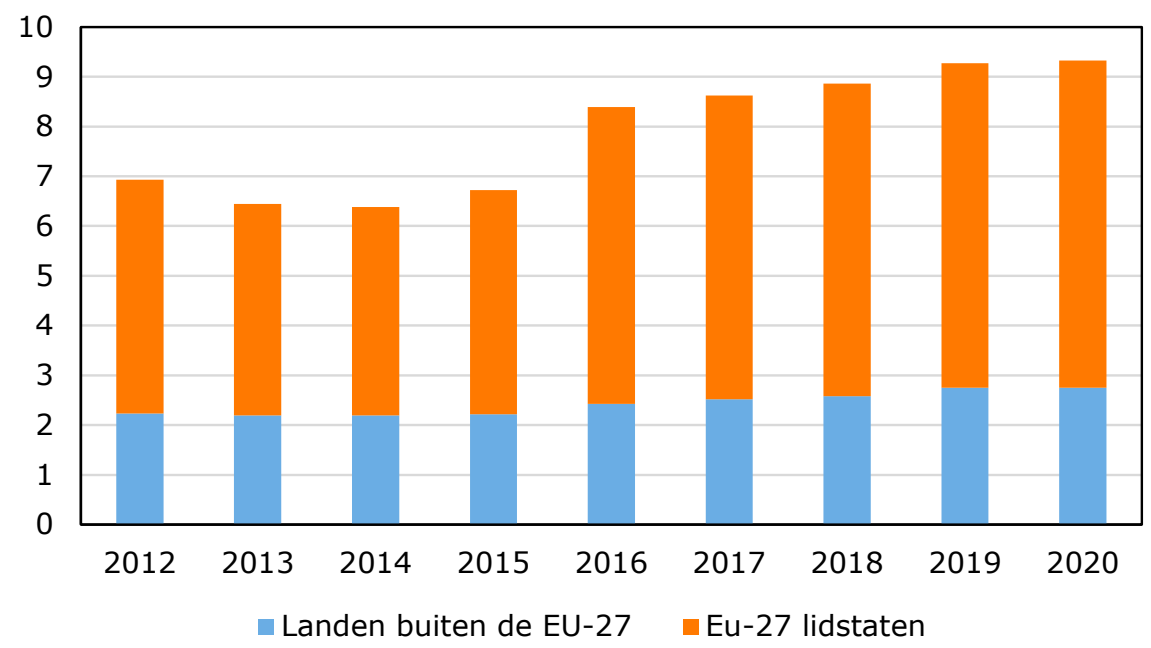

Figuur 2.1 Export van Nederland van sierteeltproducten in miljard euro, 2012-2020 Bron: Eurostat. 


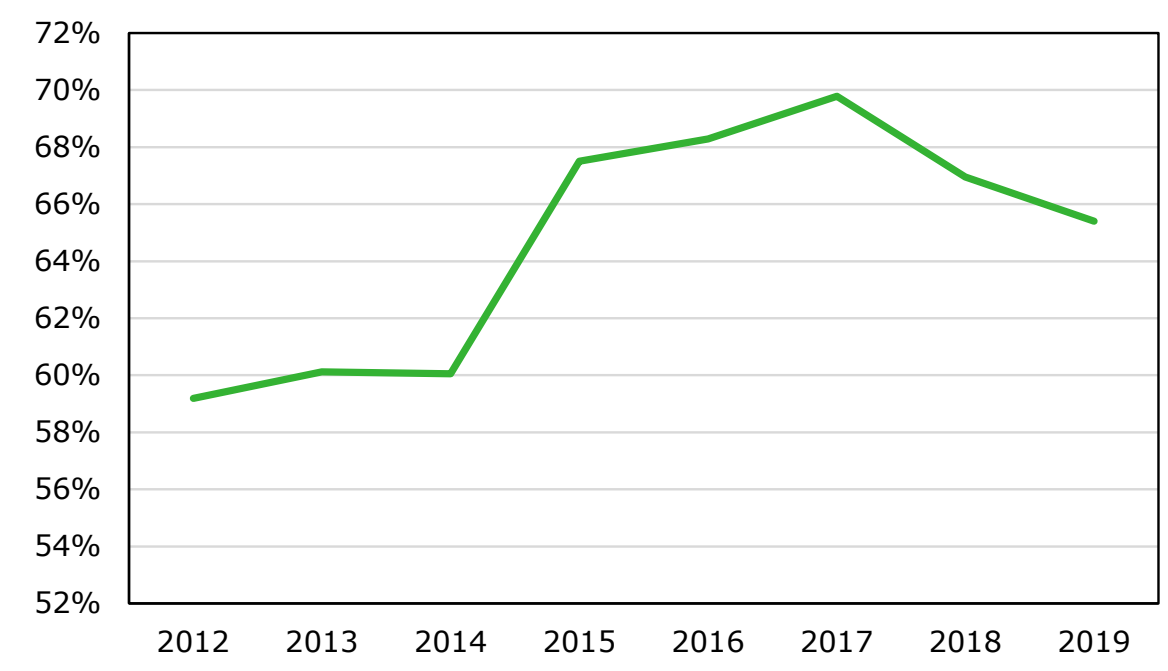

Figuur 2.2 Aandeel van Nederland in totale import van sierteeltproducten in de EU-27 en het Verenigd Koninkrijk in \%, 2012-2019

Bron: Eurostat.

De Europese sierteeltsector heeft een geschatte productiewaarde van ruim 18 miljard euro (EU en het Verenigd Koninkrijk), waarvan Nederland bijna 6 miljard voor zijn rekening neemt (tabel 2.2). Ook op groothandelsniveau is Nederland koploper met ruim 10,6 miljard euro aan omzet. De totaal omzet in Europa op groothandelsniveau heeft een waarde van 38 miljard euro, wat Nederland een aandeel van $28 \%$ geeft. Op detailhandelsniveau wordt de waarde van bloemen, planten, bollen en boomkwekerijartikelen geschat op bijna 58 miljard euro. De grootste afzetmarkten in Europa zijn Duitsland, Frankrijk, Italië en het Verenigd Koninkrijk.

Tabel 2.2 Productiewaarde en consumptie van sierteeltproducten in geselecteerde landen en EU total in $\mathrm{mln}$. euro, en \% van het totaal, 2019

\begin{tabular}{lrrrrrr} 
& \multicolumn{3}{c}{ Productie } & \multicolumn{2}{c}{ Groothandel } & \multicolumn{2}{r}{ Detailhandel } \\
& Mln. euro & $\%$ & Mln. euro & $\%$ & Mln. euro & $\%$ \\
\hline Duitsland & 2.130 & 12 & 6.010 & 16 & 12.590 & 22 \\
\hline Frankrijk & 1.830 & 10 & 4.150 & 11 & 9.100 & 16 \\
\hline Italië & 2.710 & 15 & 4.420 & 12 & 8.410 & 15 \\
\hline Nederland & 5.950 & 33 & 10.680 & 28 & 3.280 & 6 \\
\hline Rest van EU-27 en Verenigd Koninkrijk & 5.500 & 30 & 12.790 & 34 & 24.590 & 42 \\
\hline Totaal & 18.120 & & 38.040 & & 57.970 & \\
\hline
\end{tabular}

Bron: Eurostat FADN en Annual detailed enterprise statistics for trade (NACE Rev. 2 G) [SBS_NA_DT_R2], AIPH, Eurostat, modelberekeningen Wageningen Economic Research Hortus model. De productiewaarde voor zover mogelijk exclusief plantmateriaal tuinbouw en champignonbroed.

De totale werkgelegenheid van de sierteeltproductie, en gespecialiseerde groothandel en sierteeltdetailhandel in Europa wordt op basis van gegevens van Eurostat geschat op 569.000 voltijdsbanen (fte; tabel 2.3). Daarvan zijn ongeveer 260.000 voltijdsbanen in de primaire sector, 55.000 in de groothandel, en 254.000 in de retail ${ }^{4}$. In aantallen werknemers is dat meer, omdat met name in de teelt en de detailhandel veel in deeltijd gewerkt wordt. In aantal werknemers wordt de werkgelegenheid in de sierteeltketen op basis van Eurostat data voor de EU en het VK samen geschat op 66.000 banen in de groothandel en 330.000 in de detailhandel. Cijfers over het aantal werknemers in de EU in de primaire sierteeltsector zijn niet voorhanden. In Nederland is de verhouding tussen fte en aantal werknemers in de primaire sierteeltsector ongeveer 1 staat tot 1,4 . In Nederland werken de meeste arbeidskrachten in de productie en groothandelsketenschakel. In andere

\footnotetext{
${ }^{4}$ Dit betreft Eurostat data over gespecialiseerde detailhandel in bloemen en planten, en dierenspeciaalzaken. Op landniveau is geen betere data verkrijgbaar. Daarnaast is er nog een werkgelegenheid in de niet gespecialiseerde detailhandel, bijvoorbeeld in supermarkten. Daarover bestaan geen statistieken en die cijfers zijn hier in de tabel niet meegenomen. In de berekeningen van het Hortus model wordt die werkgelegenheid meegenomen op basis van een zelfde arbeidsbehoefte per euro omzet als in de bloemendetailhandel.
} 
landen zoals Duitsland en in het Verenigd Koninkrijk werken meer mensen in de detailhandel dan in Nederland. Hierdoor komen die landen qua werkgelegenheid in de totale keten boven Nederland uit.

Tabel 2.3 Geschatte werkgelegenheid in de sierteeltsector in geselecteerde landen en EU totaal in voltijdsbanen, in 2018

\begin{tabular}{lrrr} 
& Productie & Groothandel & Detailhandel, a) \\
Duitsland & 28.000 & 9.000 & 64.000 \\
\hline Frankrijk & 25.000 & 3.000 & 24.000 \\
\hline Nederland & 40.000 & 16.000 & 52.000 \\
\hline Verenigd Koninkrijk & 20.000 & 4.000 & 69.000 \\
\hline Rest van EU-27 en Verenigd Koninkrijk & 146.000 & 23.000 & 57.000 \\
\hline Totaal & 260.000 & 55.000 & 95.000 \\
\hline
\end{tabular}

a) Retail sale of flowers, plants, seeds, fertilisers, pet animals and pet food in specialised stores. Deze cijfers wijken iets af van de totale

werkgelegenheid omdat daarin marktverkoop en supermarkten ontbreken. Aan de andere kant is juist dierenspeciaalzaken hierin meegenomen. Betere data zijn op landniveau op dit moment niet beschikbaar.

Bron: Eurostat FADN en Annual detailed enterprise statistics for trade (NACE Rev. 2 G) [SBS_NA_DT_R2], AIPH, Eurostat, modelberekeningen Wageningen Economic Research. 


\section{Btw op sierteeltproducten}

De btw is een belasting op de toegevoegde waarde die overheden heffen op producten en diensten. De btw wordt over het algemeen betaald door de eindverbruiker, dat wil zeggen dat bedrijven die btw betalen over intermediaire inputs in de productie deze btw terug kunnen vragen. Daardoor is het de consument of de overheid die uiteindelijk btw betaald.

EU-landen hanteren uiteenlopende btw-tarieven (tabel 3.1). Luxemburg heeft met $17 \%$ het laagste algemene tarief en Hongarije met $27 \%$ het hoogste algemene btw-tarief. Naast een algemeen tarief kunnen landen ook een verlaagd tarief hanteren. Op basis van EU-richtlijn 2006/112/EG artikel 122 mag het verlaagde btw-tarief ook worden toegepast op sierteeltproducten (snijbloemen, tuin- en potplanten, bloembollen en boomkwekerijproducten). Op dit moment wordt het verlaagde tarief voor sierteeltproducten toegepast in 13 lidstaten (tabel 3.1). In Nederland is in 2019 het verlaagde btwtarief verhoogd van $6 \%$ naar $9 \%$. Voorbeelden uit het verleden kunnen worden gebruikt om te laten zien wat de gevolgen van een verhoging van de btw zijn. In Spanje gold van 2012 tot en met 2014 ook het reguliere (hoge) btw-tarief voor sierteeltproducten. Dat heeft een behoorlijke negatieve impact gehad op de vraag naar bloemen en planten; de omzet van bloemisten daalde met ruim $25 \%$ tussen 2012 en 2014. Spanje heeft in 2015 het lage btw-tarief opnieuw ingevoerd. In Kader 1 is beschreven wat er in Spanje is gebeurd tussen 2012 en 2015, nadat de btw op sierteeltproducten was verhoogd. Ook in Frankrijk is eerder een wijziging van het btw-tarief op sierteeltproducten geweest in 1991. Dit had ook negatieve gevolgen voor de aankopen van bloemen en planten en de werkgelegenheid in de keten (zie Kader 2).

Tabel 3.1 Btw-tarieven in de EU en het Verenigd Koninkrijk in \%, 2019

\begin{tabular}{|c|c|c|c|c|}
\hline & Lage tarief & Algemeen tarief & Tarief sierteelt & Verschil \\
\hline België & $6 / 12$ & 21,0 & 6,0 & 15,0 \\
\hline Bulgarije & 9 & 20,0 & 20,0 & - \\
\hline Denemarken & geen & 25,0 & 25,0 & - \\
\hline Duitsland & 7 & 19,0 & 7,0 & 12,0 \\
\hline Frankrijk & $5,5 / 10$ & 20,0 & 10,0 & 10,0 \\
\hline Griekenland & $6 / 13$ & 24,0 & 24,0 & - \\
\hline Hongarije & $5 / 18$ & 27,0 & 27,0 & - \\
\hline Ierland & $9 / 13,5$ & 23,0 & 13,5 & 9,5 \\
\hline Litouwen & $5 / 9$ & 21,0 & 21,0 & - \\
\hline Luxemburg & $3 / 8$ & 17,0 & 8,0 & 9,0 \\
\hline Malta & $5 / 7$ & 18,0 & 18,0 & - \\
\hline Nederland & 9 & 21,0 & 9,0 & 12,0 \\
\hline Oostenrijk & $10 / 13$ & 20,0 & 13,0 & 7,0 \\
\hline Polen & $5 / 8$ & 23,0 & 8,0 & 15,0 \\
\hline Portugal & $6 / 13$ & 23,0 & 6,0 & 17,0 \\
\hline Roemenië & $5 / 9$ & 19,0 & 19,0 & - \\
\hline Slovenië & $5 / 9,5$ & 22,0 & 9,5 & 12,5 \\
\hline
\end{tabular}

Bron: Europese Commissie, taxud.c.1 (2019) - EN. 
De effecten van de btw-regeling op de consumentenprijzen van sierteeltproducten verschilt van land tot land, afhankelijk van de hoogte van de tarieven. In Ierland, Luxemburg, Oostenrijk en Tsjechië is het verschil tussen beide tarieven klein. In Portugal, België, Frankrijk, Nederland, Polen en Slovenië is het verschil tussen de tarieven groot en dus ook de mogelijke effecten op de prijzen.

\section{Kader 1 Btw verhoging in Spanje in 2012}

Spanje heeft in juli 2012 de btw-regeling voor sierteeltproducten afgeschaft. De btw op sierteeltproducten werd verhoogd van $8 \%$ tot $21 \% .{ }^{5}$ Deze verhoging heeft een negatieve impact gehad op de omzet van Spaanse bloemisten. Deze is tussen 2012 en 2014 met ruim 25\% afgenomen. Dit ligt mede aan de economische en financiële crisis, maar de omzet van Spaanse bloemisten is in deze periode wel hard onderuit gegaan. ${ }^{6}$ Volgens de Spaanse bloemisten autoriteit AEFI is $23 \%$ van haar leden failliet gegaan tussen 2012-2014.

De vraaguitval heeft waarschijnlijk ook zijn weerslag gehad op de Spaanse import van sierteeltproducten vanuit Nederland. Deze vertoonde in de winter van 2012-2013 een sterke dip (Figuur 3.1). ${ }^{7}$ Vervolgens is de import uit Nederland geleidelijk weer gestegen, gedeeltelijk door verbeterende economische omstandigheden en gedeeltelijk door vervanging van Spaanse sierteeltproducten door import uit Nederland. De Spaanse sierteeltsector heeft een behoorlijke krimp doorgemaakt in deze periode waardoor Spanje meer is gaan importeren. De import van sierteeltproducten is echter ook al voor de verhoging van de btw gedaald. Het effect van de economische recessie vanaf 2008 is daarvoor verantwoordelijk. De grootste daling van het inkomen was echter in 2012 reeds voorbij en het lijkt aannemelijk dat de dip in 2012-2013 voor een aanzienlijk deel door de btw-verhoging is veroorzaakt. Spanje heeft de btw-regeling voor sierteeltproducten in 2015 weer ingevoerd en nu geldt een verlaagd tarief van $10 \%$.

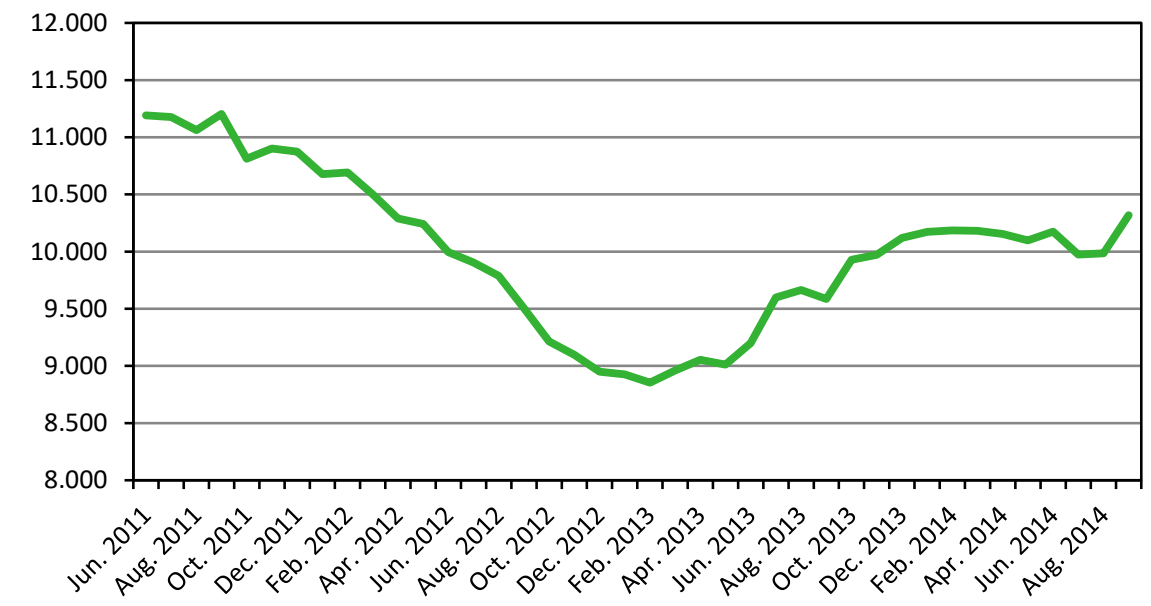

Figur 3.1 Nederlandse export van sierteeltproducten naar Spanje, in 1.000 euro, 12-maandelijks gemiddelde Bron: AEFI 2014 en Eurostat 2015.

Dit kader is eerder gepubliceerd in Bunte en Van Galen (2015), en hierboven alleen tekstueel iets aangepast.

\footnotetext{
5 Twee tot drie procent van de btw-verhoging was aan een generieke verhoging van alle btw-tarieven te wijten.

6 In de periode tussen 2006 en 2012 daalde de omzet van bloemisten al met 10,5\% elke twee jaar.

$7 \mathrm{Er}$ is een 12-maandelijks gemiddelde bepaald om de maandelijkse fluctuaties uit de cijfers te halen en de trendmatige ontwikkeling te laten zien.
} 
Kader 2 Een praktijkervaring: een voorbeeld uit Frankrijk

In augustus 1991 werd het btw-tarief voor sierteeltproducten in Frankrijk veranderd van het lage naar het hoge tarief: van 5,5\% naar 18,6\%. De netto-omzet van de detailhandel in sierteeltproducten daalde van 17,5 miljard frank in 1991 naar 15,3 miljard frank in 1992. De bruto-omzet in de detailhandel steeg licht van 18,5 naar 18,8 miljard frank. Consumenten gaven ongeveer hetzelfde bedrag aan sierteeltproducten uit in 1991 en 1992. De overheid ontving simpelweg een groter deel van de consumentenuitgaven.

Vanwege de lagere netto-omzet in de detailhandel daalde de werkgelegenheid in de sierteeltketen met 5.000 personen in 1992 en 6.000 personen in 1993. De overheid verhoogde haar btw-inkomsten, maar dit ging ten kosten van lagere inkomstenbelastingen en waarschijnlijk hogere werkloosheidsuitgaven. De maatregel werd daarom teruggedraaid in 1993. Het lage btw-tarief werd wederom toegepast op sierteeltproducten in Frankrijk.

Bron: ADAVF 1993. Dit kader is eerder gepubliceerd in Bunte en Van Galen (2015) 


\section{$4 \quad$ Methode}

\section{$4.1 \quad$ Inleiding}

In deze studie wordt gebruikgemaakt van een partieel evenwichtsmodel Hortus dat speciaal ontwikkeld is door Wageningen Economic Research om de effecten van vraag- en aanbodveranderingen op de Europese tuinbouw te simuleren (Bunte en Van Galen, 2005). In dit hoofdstuk wordt kort het model en een aantal van de belangrijke aannames besproken.

\subsection{Drie scenario's}

Er zijn in deze studie drie scenario's uitgewerkt:

1. een scenario waarin Nederland unilateraal het btw-tarief voor sierteeltproducten verandert van het lage tarief van $9 \%$ naar het algemene tarief van $21 \%$

2. een scenario waarin alle twaalf andere EU-landen die op dit moment het lage tarief op sierteeltproducten toepassen, overgaan tot het algemene tarief en

3. een scenario waarin zowel Nederland als de andere twaalf EU-landen met een verlaagd tarief besluiten om sierteeltproducten met het algemene tarief te belasten.

Het derde scenario is gebaseerd op de verwachting dat het Nederlandse beleid ten aanzien van het btw-regime op sierteeltproducten wordt gevolgd door andere EU-landen vanwege het Europese marktleiderschap van Nederland in de sierteeltproductie en -handel. Daarnaast heeft Nederland als marktleider het grootste belang en een leidende positie om in de Europese Raad en op belangrijke Europese exportmarkten (behoud van) een laag btw-tarief op sierteeltproducten te bepleiten. Die positie wordt in belangrijke mate verzwakt als in Nederland zelf het algemene btw-tarief wordt toegepast.

\subsection{Hortus-model}

De effecten van de btw-verhogingen zijn berekend met behulp het Hortus-model, een vraag- en aanbodmodel voor tuinbouwproducten in de EU-27, het Verenigd Koninkrijk, en de rest van de wereld als geheel. ${ }^{8}$ Het Hortus-model onderscheidt (in versie 10) 24 verschillende tuinbouwproducten (groenten, fruit, en sierteelt). De onderscheiden sierteeltproducten zijn snijbloemen, potplanten (kamerplanten, balkonplanten en perkplanten), boomkwekerijproducten, en bloembollen. In het model worden productie, internationale handel en consumptie aan elkaar gerelateerd middels (getrapte) vraag- en aanbodvergelijkingen en vraag- en aanbodsubstitutie-elasticiteiten. Voor de sierteeltsector zijn bovendien prijselasticiteiten in het model opgenomen die de vraag naar sierteeltproducten beïnvloeden als de prijzen veranderen. Het model kent bovendien verschillen in productietechnologie tussen landen, wat tot uitdrukking komt in verschillen in kapitaal en arbeidsintensiteit in de productie en het gebruik van intermediaire inputs. Voor de huidige scenario's zijn deze verschillen in productietechnologie tussen landen echter minder belangrijk. De effecten van een btw-verhoging worden met name gevoeld door veranderingen in de consumentenvraag. Omdat Nederland een belangrijk producent van sierteeltproducten in Europa is, werkt een btw-verhoging in belangrijke afzetmarkten in Europa ook in Nederland relatief sterk door.

\footnotetext{
8 Voor de rest van de wereld ontbreken voor de sierteeltproducten een deel van de gegevens over met name productie en consumptie. De resultaten van het model voor de rest van de wereld zijn daardoor minder betrouwbaar en worden in deze rapportage niet weergegeven.
} 
In het model wordt de aanname gemaakt dat de opeenvolgende markten in de productie- en distributieketen gekenmerkt worden door volkomen concurrentie. Dit betekent dat wij ervan uitgaan dat er geen partijen in de keten zijn die marktmacht uitoefenen. Dit is een geldige aanname gegeven het aantal en de omvang van bedrijven die opereren in de keten. De aanname dat de keten gekenmerkt wordt door volkomen concurrentie impliceert dat de toename in het btw-tarief in eerste instantie volledig wordt doorberekend in de consumentenprijs. Uit onderzoek van Bunte en Kuiper (2008) blijkt inderdaad dat een verhoging van de producentenprijs met één procent leidt tot een verhoging van de consumentenprijs met één procent. Deze aanname is verder te verdedigen doordat er in Nederland in 2020 ruim 8.000 primaire sierteeltbedrijven waren en 2.400 bedrijven in de groothandel in bloemen en planten, en ruim 3.000 bedrijven in de detailhandel van bloemen en planten, 500 tuincentra, en 600 bedrijven in de markthandel in bloemen en planten. ${ }^{9}$ Ondanks dat er steeds grotere groothandelsbedrijven ontstaan, speelt bovendien de veilingklok voor bloemen en planten nog steeds een belangrijke rol. Daaruit kan worden geconcludeerd dat de prijsvorming in de detailhandel en de rest van de keten voor sierteelt competitief is en dat veranderingen van het btwtarief volledig worden doorberekend. De veranderingen in de belastingdruk komen dus bij de consument te liggen. Het CPB (2003) heeft vergelijkbare conclusies getrokken voor arbeidsintensieve diensten.

Het model berekent op basis van een initiële set van gegevens over productie, handel en consumptie en onder de voorwaarden van de gehanteerde parameters, een nieuw evenwicht na een schok als gevolg van de veranderingen in de btw. De uitkomsten van het model zijn procentuele veranderingen ten opzichte van de initiële situatie. De gevolgen voor de werkgelegenheid worden vervolgens buiten het model berekend met behulp van productiviteitsindicatoren voor de respectievelijke stadia in de keten, met behulp van de omzet per voltijdbaan (fte). De achterliggende cijfers zijn gebaseerd op gegevens van het Farm Accountancy Data Network (FADN), en Annual detailed enterprise statistics for trade (NACE Rev. 2 G) [SBS_NA_DT_R2]. Deze cijfers maken geen onderscheid tussen de productgroepen binnen de sierteeltketen. Voor de effecten op de werkgelegenheid wordt daarom gerekend met eenzelfde omzet per fte voor iedere productgroep.

Drie belangrijke parameters van het model worden hier nader toegelicht omdat ze een relatief grote invloed hebben op de uitkomsten: de prijselasticiteiten, het aandeel van de bedrijvenmarkt, en de gehanteerde markups om de omzet op groothandelsniveau te schatten. De prijselasticiteit bepaalt in welke mate een prijsverandering leidt tot een verandering van de vraag door consumenten. Hoe groter (meer negatief) de prijselasticiteit, hoe groter het effect op de vraag. In eerdere studies zijn de prijselasticiteiten voor sierteeltproducten gebaseerd op onderzoek van Bunte et al. (2007). Uit dat onderzoek kwam een prijselasticiteit van de vraag van $-1,1$ voor snijbloemen en potplanten en $-1,5$ voor tuinproducten. De prijselasticiteiten zijn geschat voor bestedingscategorieën die het Centraal Bureau voor de Statistiek (CBS) onderscheidt. Tuinproducten omvatten alle producten die huishoudens voor de tuin aankopen: bloembollen, tuinplanten, boomkwekerijproducten, maar ook tuingereedschap. De gevonden prijselasticiteit van de vraag voor zowel binnen- als buitenplanten in Nederland duidt erop dat de consumentenvraag naar snijbloemen, potplanten en tuinartikelen gevoelig is voor veranderingen in de consumentenprijs. Voor dit rapport heeft Royal Floraholland door GfK in 2021 opnieuw onderzoek laten doen naar de prijselasticiteit van sierteeltproducten. Op basis van panelonderzoek onder consumenten, waarin verschillende keuzes aan consumenten voorgelegd zijn met betrekking tot aankopen van bloemen en planten met uiteenlopende prijzen, heeft GfK de volgende prijselasticiteiten bepaald, die in de huidige modelversie zijn gebruikt:

- snijbloemen: $-1,6$

- kamerplanten: $-1,3$

- tuinplanten: $-1,3$

- bloembollen: $-1,5$.

Ten opzichte van de eerdere studies uit 2007, 2010, en 2015 betekent dat een kleine stijging van de prijselasticiteit van snijbloemen, potplanten (kamerplanten), en een kleine daling van de prijselasticiteit van tuinplanten (nota bene, een stijging van de prijselasticiteit komt overeen met een

9 Bron: CBS Statline. https://opendata.cbs.nl/statline/\#/CBS/nl/dataset/81302ned/table?dl=4F5A2 en https://opendata.cbs.nl/statline/\#/CBS/nl/dataset/81589NED/table?dl=4F5A5 en https://opendata.cbs.nl/\#/CBS/nl/dataset/81589NED/table?dl=4F6FC 
lagere or groter negatieve waarde van de prijselasticiteit). Boomkwekerijproducten zoals bos- en haagplantsoen, laan- en parkbomen, rozenstruiken, sierconiferen, sierheesters, en vruchtbomen vielen buiten de scope van het GfK-onderzoek. Daarvoor hebben we de laagst gevonden elasticiteit van $-1,3$ aangehouden. In het algemeen komen de gevonden elasticiteiten echter goed overeen met de eerdere studies.

Een andere belangrijke parameter die in het model wordt gebruikt, betreft het aandeel van de zakelijke markt in de totale afzet van in een land. Omdat bedrijven btw kunnen terugvragen zal een btw-stijging op de vraag van bedrijven geen directe invloed hebben. Hoe hoger het percentage bedrijvenmarkt, hoe lager de effecten van een btw-verhoging uitpakken. Op basis van gegevens van Royal Floraholland is aangenomen dat voor snijbloemen en potplanten ongeveer $85 \%$ van de afzet in Nederland gericht is op de consumentenmarkt en $15 \%$ op de zakelijke markt (bedrijven en instellingen). Voor boomkwekerij en bloembollen zijn geen recente cijfers bekend, maar is een percentage van $30 \%$ zakelijke markt aangenomen. De overheid betaalt wel btw en wordt hier daarom niet tot de zakelijke markt gerekend.

In Bunte et al. (2007) wordt de institutionele markt als totaal van bedrijvenmarkt en overheid voor snijbloemen en potplanten op ongeveer $23 \%$ en $26 \%$ geschat. Voor boomkwekerij en bloembollen zijn geen recente data beschikbaar. In Bunte et al. (2007) werd de institutionele markt voor boomkwekerij op $40 \%$ geschat. Een belangrijk deel daarvan is de overheid, maar er zijn geen cijfers over die omvang. Wij nemen in deze studie aan dat de bedrijvenmarkt $30 \%$ van de afzet is. In eerdere doorrekeningen is ook met $10 \%$ gerekend. Voor bloembollen is er ook een wijziging opgetreden in de inzichten over de bedrijvenmarkt. In Bunte et al. (2007) en latere studies in 2015 werd ervan uitgegaan dat $90 \%$ van de bloembollen voor de institutionele markt (lees broeierij) bestemd was. Rabobank (2018) geeft aan dat $70 \%$ voor de broeierij bestemd is en $30 \%$ voor droogverkoop. Omdat de bloembollensector echter ook wordt geraakt door een daling van de vraag naar bloemen (immers de bollen die voor de broeierij bestemd zijn zullen in zekere zin ook als bloemen worden verkocht), is in deze versie besloten om het aandeel van de bedrijvenmarkt voor bloembollen te verlagen naar $30 \%$, gelijk aan boomkwekerijproducten.

Ten slotte zijn er aannames gemaakt ten aanzien van de marge die de detailhandel maakt ten opzichte van de groothandel. Deze gegevens worden in het model gebruikt om de consumptie te schatten van sierteeltproducten en de omzet op zowel groothandelsniveau als detailhandelsniveau. Omdat in de statistieken van de meeste landen geen cijfers beschikbaar zijn over de totale omzet van sierteeltproducten gebruiken we daarvoor de aanname dat de omzet in de detailhandel twee keer de inkoopwaarde is voor planten, bomen en bollen, en drie keer de inkoopwaarde voor snijbloemen en boeketten. Bij die laatste categorie veronderstellen we meer werk voor de detailhandel. Deze data zijn vergeleken met de bekende schattingen van consumptie in Nederland en een aantal andere landen (vertrouwelijke cijfers van Royal Floraholland). Daaruit blijkt dat de inschatting van deze markup voor de detailhandel klopt. Ook gegevens van Eurostat laten zien dat de verkoopwaarde van bloemendetailhandel 1,8 keer zo groot was als de inkoopwaarde van de handelsproducten in 2018 in Nederland. Een deel van die ingekochte producten bestaat echter uit potten en verpakkingen. Op basis van een inschatting is de inkoopwaarde daarop aangepast. De markup tussen productie en groothandel wordt ingeschat op ongeveer 1,4. 


\section{Doorrekening van effecten}

\section{$5.1 \quad$ Inleiding}

In dit hoofdstuk worden de resultaten van de modelberekeningen van de effecten op de werkgelegenheid en omzet in de sierteeltsector weergegeven voor de drie scenario's. Eerst wordt het scenario besproken waarin alleen in Nederland de btw op sierteeltproducten wordt verhoogd van $9 \%$ naar $21 \%$. Daarna komen de scenario's aan bod waarbij in twaalf andere EU-landen de btw wordt verhoogd en waarin zowel in Nederland als in andere twaalf EU-landen de btw wordt verhoogd. De resultaten laten zien dat de effecten voor de Nederlandse sierteelt aanzienlijk groter worden naarmate meer landen besluiten de btw te verhogen.

\subsection{Scenario 1: Verhoging btw in Nederland}

Als in Nederland het algemene btw-tarief wordt toegepast op sierteeltproducten in plaats van het lage tarief zullen de consumentenprijzen stijgen met $11 \% .{ }^{10}$ Als gevolg hiervan zal de vraag naar sierteeltproducten in Nederland dalen. Het effect op de vraag in Nederland - via de prijselasticiteit van de vraag (-1,6 voor snijbloemen, $-1,5$ voor bloembollen en -1,3 voor kamerplanten en tuinplanten) wordt iets gedempt doordat een deel van de afzet niet bij consumenten gekocht wordt maar door bedrijven die daarover de btw kunnen terugvragen. De zakelijke markt voor snijbloemen en potplanten is ingeschat op $15 \%$. Voor boomkwekerijproducten en bloembollen is de zakelijke markt ingeschat op 30\%. De vraaguitval heeft vervolgens effecten op de detailhandelsomzet en de productie van sierteeltproducten in Nederland. Zowel het areaal als de prijzen passen zich aan. Uiteindelijk resteert een negatief effect op de productie, de omzet en de werkgelegenheid (zie tabel 5.1).

Omdat de Nederlandse sierteelt voor een belangrijk deel op de export is georiënteerd, is het effect van een verandering in het btw-tarief op de Nederlandse productie en werkgelegenheid in dit scenario beperkter dan in scenario 2 en 3. Het effect is min of meer gelijk aan de procentuele verandering van de omzet op het niveau van de detailhandel maal het aandeel van Nederland in de verkoop van Nederlandse sierteeltproducten.

In totaliteit is een effect berekend van 80 miljoen euro omzetverlies voor de primaire sierteeltsector $(-1,3 \%), 170$ miljoen euro voor de groothandel $(-1,6 \%)$ en 420 miljoen euro verlies aan consumentenomzet $(-13 \%)$. Procentueel gezien wordt de primaire productie van potplanten en de boomkwekerij met respectievelijk $-1,8$ en $-1,6 \%$ het meest getroffen. De omzet van de snijbloementeelt daalt met ongeveer $0,9 \%$ en bloembollenteelt daalt met 0,5\%. In vergelijking met Bunte en Van Galen (2015) valt vooral op dat de effecten op de boomkwekerij en de potplantenteelt lager zijn in de nieuwe doorrekeningen. Dat wordt veroorzaakt doordat enerzijds het effect op de prijzen lager is omdat het verlaagde btw-tarief in 2019 is verhoogd van 6\% naar $9 \%$ en boomkwekerijproducten relatief veel voor de Nederlandse markt bestemd zijn, en anderzijds door een aanpassing in de aannames van het model ten aanzien van het belang van de zakelijke markt. Voor boomkwekerijproducten is in deze versie van het model gerekend met een aandeel van 30\% voor de zakelijke markt, ten opzichte van $10 \%$ in de eerdere modelberekeningen van Bunte en Van Galen (2015). Daarnaast speelt mee dat de productie en handel in de verschillende productgroepen veranderd is.

Het effect op de werkgelegenheid is een verlies van ongeveer 2.830 voltijdsbanen. Daarvan gaan de meeste banen verloren in de detailhandel (circa 2.060), 520 in de primaire sector, en ongeveer 250 in de groothandel. Ten opzichte van eerdere studies is het effect op de detailhandel groter geworden omdat de omzet per voltijdsmedewerker in de detailhandel is gedaald. In de primaire sector is de omzet per

\footnotetext{
${ }^{10}$ Berekend als (121/109)-1 x 100\%.
} 
medewerker juist gestegen ten opzichte van 2013 waardoor het effect op de werkgelegenheid kleiner wordt.

Tabel 5.1 Effecten van een verhoging van het btw-tarief in Nederland op de omzet van de sierteeltsector in Nederland, in miljoen euro en in \%

\begin{tabular}{lrrrrrr} 
& Productie & \multicolumn{1}{c}{ Groothandel } & & Detailhandel \\
& MIn euro & $\%$ & Mln euro & $\%$ & Mln euro \\
\hline Bloembollen & 0 & $-0,5$ & -10 & $-0,7$ & -20 & -11 \\
\hline Boomkwekerij & -20 & $-1,6$ & -40 & $-2,0$ & -80 & -10 \\
\hline Potplanten & -30 & $-1,8$ & -60 & $-2,3$ & -120 \\
\hline Snijbloemen & -20 & $-0,9$ & -70 & $-1,4$ & -200 \\
\hline Totaal & -80 & $-1,3$ & -170 & $-1,6$ & -420 & -13 \\
\hline
\end{tabular}

Nota bene: de omzetten van de verschillende schakels kunnen niet bij elkaar worden opgeteld vanwege de dubbeltelling die dan ontstaat. Bron: Wageningen Economic Research, Hortus-model. Afgerond op 10-tallen.

Tabel 5.2 Effecten van een verhoging van het btw-tarief in Nederland op de werkgelegenheid in de sierteeltsector in Nederland, in voltijdsbanen en in \%

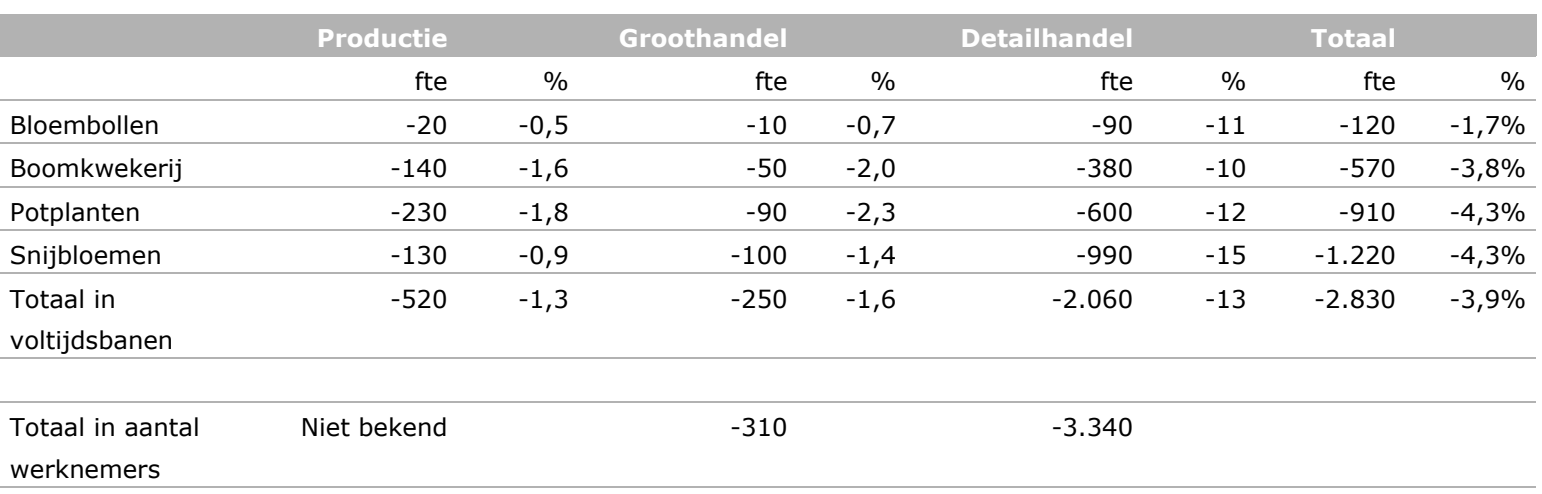

Bron: Wageningen Economic Research, Hortus-model. Afgerond op 10-tallen fte.

\subsection{Scenario 2: Verhoging btw in andere EU-landen dan Nederland}

Het tweede doorgerekende scenario is dat waarin de twaalf EU-landen buiten Nederland die nu het verlaagde tarief op sierteeltproducten hanteren allemaal de btw verhogen naar het algemene tarief. Tot de landen die in dit scenario de btw verhogen behoren de belangrijke afzetmarkten Duitsland en Frankrijk. Dit heeft grote gevolgen voor de vraag in die markten en dus ook voor de vraag naar Nederlandse exportproducten.

De omzet van de detailhandel in sierteeltproducten in de EU-27 en het Verenigd Koninkrijk zal afnemen met 4,7 miljard euro (zie tabel 5.3). De grootste effecten worden verwacht in Duitsland met een omzetverlies van 1,6 miljard euro in de detailhandel en Italië met ruim 1 miljard euro verlies aan detailhandelsomzet. En ook in Frankrijk zal de detailhandelsomzet naar verwachting met bijna 900 miljoen euro dalen.

In Nederland is het effect op de detailhandel beperkt, en zelfs licht positief door een beperkte prijsdaling die zorgt voor een toename van de vraag. Er is immers geen vraaguitval in de Nederlandse binnenlandse consumptie omdat in dit scenario de btw in Nederland niet verandert. Er is echter wel een groot effect zichtbaar op de Nederlandse primaire sector en groothandel. Als belangrijke producent en exporteur heeft Nederland in dit scenario wel last van btw-verhogingen in de andere EUlanden. De kwekers leveren ongeveer 350 miljoen euro omzet in op een totaal van bijna 6 miljard euro (-6\%). De groothandel verliest ongeveer 620 miljoen euro omzet (eveneens $-6 \%$ ). 
In Nederland veroorzaakt dit scenario een totaal verlies aan werkgelegenheid van 3.190 voltijdsbanen (zie tabel 5.4). Daarvan zijn er 2.370 in de primaire sector en 890 in de groothandel. In de detailhandel komen er een aantal banen bij, omdat door de prijsdruk op de Europese markt en het ontbreken van een btw-verhoging in Nederland de consumentenprijzen in Nederland iets zullen dalen wat een positief effect heeft op de vraag van consumenten in Nederland. In totaal leidt dit scenario tot een verlies van bijna 54 duizend banen in de EU-27 en het Verenigd Koninkrijk samen- en dus ook in Nederland vanwege het belang van onze productie en export van sierteeltproducten.

Tabel 5.3 Effecten van een btw-stijging in andere EU-landen op de omzet in de sierteeltketen in de EU-27 en het Verenigd Koninkrijk, in miljoen euro en in \%

\begin{tabular}{|c|c|c|c|c|c|c|}
\hline \multirow{3}{*}{ 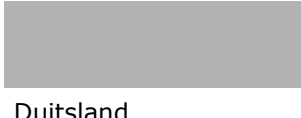 } & \multicolumn{2}{|l|}{ Productie } & \multicolumn{2}{|c|}{ Groothandel } & \multicolumn{2}{|c|}{ Detailhandel } \\
\hline & mln. euro & $\%$ & mln. euro & $\%$ & mln. euro & $\%$ \\
\hline & -210 & -10 & -680 & -11 & -1.630 & -13 \\
\hline Italië & -280 & -10 & -470 & -11 & -1.020 & -12 \\
\hline Nederland & -350 & -6 & -620 & -6 & 10 & 0 \\
\hline Portugal & -40 & -15 & -70 & -15 & -160 & -19 \\
\hline Spanje & -120 & -10 & -190 & -10 & -390 & -12 \\
\hline Rest van EU-27 en VK & -70 & 0 & -210 & -1 & -360 & -1 \\
\hline Totaal & -1.290 & -7 & -2.780 & -7 & -4.740 & -8 \\
\hline
\end{tabular}

Nota bene: de omzetten van de verschillende schakels kunnen niet bij elkaar worden opgeteld vanwege de dubbeltelling die dan ontstaat.

Bron: Wageningen Economic Research, Hortus-model. Afgerond op 10-tallen.

Tabel 5.4 Effecten van een btw-stijging in andere EU-landen op de werkgelegenheid in de sierteeltketen in de EU-27 en het Verenigd Koninkrijk, in voltijdsbanen en in \%

\begin{tabular}{|c|c|c|c|c|c|c|c|c|}
\hline & \multicolumn{2}{|c|}{ Productie } & \multicolumn{2}{|c|}{ Groothandel } & \multicolumn{2}{|c|}{ Detailhandel } & \multicolumn{2}{|l|}{ Totaal } \\
\hline & Fte & $\%$ & Fte & $\%$ & Fte & $\%$ & Fte & $\%$ \\
\hline Duitsland & -2.810 & -10 & -1.290 & -11 & -11.820 & -13 & -15.920 & -12 \\
\hline Italië & -3.400 & -10 & -1.150 & -11 & -3.140 & -12 & -7.690 & -11 \\
\hline Nederland & -2.370 & -6 & -890 & -6 & 70 & 0 & -3.190 & -4 \\
\hline Portugal & -1.770 & -15 & -630 & -15 & -1.780 & -19 & -4.180 & -16 \\
\hline Spanje & -2.490 & -10 & -1.210 & -10 & -2.590 & -12 & -6.290 & -11 \\
\hline Rest van EU-27 en VK & -.1020 & -1 & -640 & -2 & -1.790 & -1 & -3.450 & -1 \\
\hline Totaal & -18.120 & -7 & -7.450 & -9 & -28.100 & -7 & -53.670 & -7 \\
\hline
\end{tabular}

Bron: Wageningen Economic Research, Hortus-model. Afgerond op 10-tallen.

\subsection{Scenario 3: Verhoging btw in hele EU}

Het derde scenario beschrijft de situatie dat zowel in Nederland als in de andere twaalf EU-landen met een verlaagd btw-tarief op sierteeltproducten de btw wordt verhoogd naar het algemene tarief. Voor de Nederlandse sierteeltketen zijn de effecten van dit scenario het grootst. In Nederland gaat de omzet in de hele keten omlaag met 430 miljoen euro in de primaire productie, 780 miljoen euro in de groothandel en 400 miljoen euro in de detailhandel (tabel 5.5). De werkgelegenheid in Nederland daalt met 6 duizend voltijdsbanen (-8\%), waarvan 2.860 in de primaire sector, 1.230 in de groothandel en 2.580 in de detailhandel (tabel 5.6).

In de hele EU-27 en het Verenigd Koninkrijk zorgt de btw-verhoging in 13 landen ervoor dat de omzet van de primaire sector daalt met 1,4 miljard euro. De omzet van de groothandel en detailhandel dalen met respectievelijk 3 en 5,1 miljard euro. Duitsland en Italië leveren het meeste omzet in, net als in het tweede scenario. In relatieve zin neemt de omzet in dit scenario ook hard af in Portugal $(-18 \%$ 
omzetverlies in de detailhandel), België (-17\%) en Polen (-15\%). In Duitsland 13\%, in Italië en Nederland 12\%, en in Frankrijk 10\%. Het effect op de primaire sector en groothandel in Nederland is in absolute zin heel groot, maar in relatieve zin iets minder dan in de meeste andere landen. Dat Nederland relatief minder hard geraakt wordt dan de andere genoemde landen komt omdat Nederland een sterke positie heeft op de internationale markten voor sierteeltproducten. Die sterke positie leidt ertoe dat de andere landen iets verder achteruit zullen gaan dan Nederland. Echter, in absolute zin is Nederland een grote producent en handelsland en wordt daarom ook navenant meer omzetverlies in Nederland gerealiseerd.

Er gaan ruim 57.000 voltijdsbanen verloren in de hele EU-27 en het Verenigd Koninkrijk (-8\%). Ook in termen van werkgelegenheid wordt met name Duitsland als relatief grote markt en producent hard getroffen met een verlies van 16.000 banen $(-12 \%)$ in totaal. De meeste banen gaan verloren in de detailhandel. In Nederland gaan in dit scenario 6.000 voltijdsbanen verloren (-8\%), waarvan ongeveer de helft in de primaire sector (tabel 5.6).

Tabel 5.5 Effecten van een btw-stijging in alle EU-landen met verlaagd tarief op de omzet in de sierteeltketen in de EU-27 en het Verenigd Koninkrijk, in miljoen euro

\begin{tabular}{|c|c|c|c|c|c|c|}
\hline & \multicolumn{2}{|c|}{ Productie } & \multicolumn{2}{|c|}{ Groothandel } & \multicolumn{2}{|c|}{ Detailhandel } \\
\hline & mln. euro & $\%$ & mln. euro & $\%$ & mln. euro & $\%$ \\
\hline België & -20 & -10 & -110 & -12 & -150 & -17 \\
\hline Frankrijk & -170 & -9 & -390 & -9 & -890 & -10 \\
\hline Italië & -300 & -11 & -490 & -11 & -1.020 & -12 \\
\hline Polen & -50 & -12 & -130 & -13 & -300 & -15 \\
\hline Spanje & -130 & -11 & -200 & -11 & -390 & -12 \\
\hline Rest van EU-27 en VK & -120 & -1 & -320 & -1 & -510 & -1 \\
\hline Totaal & -1.420 & -8 & -3.030 & -8 & -5.130 & -9 \\
\hline
\end{tabular}

Nota bene: de omzetten van de verschillende schakels kunnen niet bij elkaar worden opgeteld vanwege de dubbeltelling die dan ontstaat. Bron: Wageningen Economic Research, Hortus-model. Afgerond op 10-tallen.

Tabel 5.6 Effecten van een btw-stijging in alle EU-landen met verlaagd tarief op de werkgelegenheid in de sierteeltketen in de EU-27 en het Verenigd Koninkrijk, in voltijdsbanen

\begin{tabular}{|c|c|c|c|c|c|c|c|c|}
\hline & \multicolumn{2}{|c|}{ Productie } & \multicolumn{2}{|c|}{ Groothandel } & \multicolumn{2}{|c|}{ Detailhandel } & \multicolumn{2}{|l|}{ Totaal } \\
\hline & fte & $\%$ & fte & $\%$ & fte & $\%$ & fte & $\%$ \\
\hline Duitsland & -3.040 & -11 & -1.340 & -12 & -11.760 & -13 & -16.140 & -12 \\
\hline Italië & -3.550 & -11 & -1.190 & -11 & -3.130 & -12 & -7.870 & -11 \\
\hline Nederland & -2.890 & -7 & -1.120 & -7 & -1.990 & -12 & -6.000 & -8 \\
\hline Portugal & -1.940 & -17 & -670 & -16 & -1.760 & -18 & -4.370 & -17 \\
\hline Spanje & -2.620 & -11 & -1.280 & -11 & -2.580 & -12 & -6.480 & -11 \\
\hline Rest van EU-27 en VK & -3.080 & -2 & -1.330 & -3 & -3.430 & -2 & -7.840 & -2 \\
\hline Totaal & -19.530 & -8 & -7.930 & -10 & -29.910 & -8 & -57.370 & -8 \\
\hline
\end{tabular}

Bron: Wageningen Economic Research, Hortus-model. Afgerond op 10-tallen.

\subsection{Effecten op de overheidsfinanciën in Nederland}

Een van de belangrijkste redenen voor de regering om het btw-tarief voor sierteeltproducten te verhogen van het lage tarief naar het algemene tarief is de beoogde toename van de overheidsinkomsten. Als men veronderstelt dat consumenten niet reageren op prijsverhogingen zullen de overheidsinkomsten na een btw-verhoging van $9 \%$ naar $21 \%$ met 360 miljoen euro per jaar stijgen naar 631 miljoen. Consumenten zullen echter wel reageren op een prijsverhoging en daardoor daalt 
de omzet en dalen ook de btw-inkomsten van de overheid. Als de effecten van het Hortus-model voor de consumentenbestedingen aan sierteeltproducten worden meegenomen, dan blijft zodoende een lager effect op de overheidsinkomsten over van (een stijging van) 226 en 229 miljoen euro afhankelijk van het scenario 1 of 3 (tabel 5.7). In scenario 2 is het effect op de btw-inkomsten heel beperkt positief door een kleine toename van de vraag, maar het btw tarief zelf verandert niet.

Wel zal er door een verlies aan werkgelegenheid in de keten op korte termijn een verlies van inkomsten uit inkomstenbelasting en een toename van de kosten van de sociale zekerheid optreden. Dat effect wordt hieronder verder uitgewerkt voor de verschillende scenario's.

Tabel 5.7 Effecten op de btw-inkomsten in Nederland in scenario 1, 2 en 3, in miljoen euro

\begin{tabular}{|c|c|c|c|}
\hline & Scenario 1 & Scenario 2 & Scenario 3 \\
\hline Netto-omzet voor verhoging & 3.006 & 3006 & 3.006 \\
\hline Btw-verhoging & $9 \%$ naar $21 \%$ & Geen & $9 \%$ naar $21 \%$ \\
\hline \multicolumn{4}{|l|}{ Met gedragsverandering: } \\
\hline Bruto-omzet na verhoging & 2.861 & 3.292 & 2.876 \\
\hline Netto-omzet na verhoging & 2.365 & 3.020 & 2.377 \\
\hline Werkelijke btw-opbrengsten & 497 & 272 & 499 \\
\hline
\end{tabular}

Bron: Hortus-model; berekeningen Wageningen Economic Research.

Door de vraaguitval raken er namelijk mensen werkloos. Werkloze mensen betalen minder belastingen en sociale premies. Er staan in scenario 1 ongeveer $2.830 \mathrm{fte}$ op het spel in Nederland. Het gemiddelde Ioon per fte in de Nederlandse agrarische sector was in 2019 ongeveer 34.500 euro. In de groothandel was dat 52.600 euro en in de detailhandel 29.200 euro. ${ }^{11}$ Gemiddeld betaalde een werknemer met een inkomen van rond 40.000 euro in 2020 ongeveer $24,5 \%$ inkomstenbelasting. Een gemiddeld inkomen van een werkloze was in 2018 volgens het CBS 11.700 euro. ${ }^{12}$ Dit betreft zowel personen met een werkloosheidsuitkering als personen met een bijstandsuitkering of anderszins. Omdat we niet op voorhand kunnen bepalen welke mensen werkloos worden en in welke mate die mensen recht hebben op een werkloosheidsuitkering, nemen we deze cijfers als uitgangspunt. ${ }^{13}$ De gemiddelde werknemer in de Nederlandse agrarische sector was in 2019 goed voor ongeveer 9.100 euro sociale premies (via werkgever) en in de groot- en detailhandel was dat respectievelijk 13.100 en 7900 euro (zie tabel 5.8).

Met deze cijfers kunnen we berekenen dat een banenverlies van $520 \mathrm{fte}$ in scenario 1 in de primaire sector leidt tot een afname van de belastinginkomsten van de overheid van $24,5 \% *$ (34.500 $11.700) * 520=3$ miljoen euro. Voor de andere twee ketenschakels is dat in scenario 1 ongeveer 3 en 9 miljoen euro. Het grootste effect op de belastinginkomsten is in scenario 1 te zien in de detailhandel. Dit betekent dat de Nederlandse overheid 14 miljoen euro derft aan belastingen. Daarnaast worden er minder sociale premies betaald. De netto-inkomsten ten gevolge van de btwverhoging in scenario 1 bedragen $226-14$ - 24 miljoen euro = 187 miljoen euro als we deze effecten ook meenemen. In scenario 3 is dat 131 miljoen euro. Dit is nog altijd een stijging van de inkomsten van de overheid op jaarbasis, maar wel veel minder dan het initiële verwachte effect. Tevens geldt dat de tijdelijk werklozen een uitkering zullen ontvangen. De kosten van de sociale zekerheid zullen

\footnotetext{
${ }^{11}$ CBS Beloning en arbeidsvolume van werknemers; bedrijfstak, nationale rekeningen https://opendata.cbs.nl/statline/\#/CBS/nl/dataset/84165NED/table?dl=4F8DB

${ }^{12}$ CBS Beroeps- en niet-beroepsbevolking; gemiddeld inkomen en arbeidspositie ; Gemiddeld persoonlijk overdrachtsinkomen. https://opendata.cbs.nl/statline/\#/CBS/nl/dataset/83687NED/table?dl=4F67A

${ }^{13}$ Het gaat hierbij om zowel mensen die voorheen een voltijdsbaan hadden als mensen die een parttimebaan hadden. Er zijn geen aparte cijfers over gemiddeld bruto-inkomen van een werkloze die voorheen een voltijdsbaan had. Omdat we de cijfers over het banenverlies wel in voltijdsbanen berekenen betekent dit een onderschatting van het effect op de uitgaven van de overheid aan werkloosheidsuitkeringen (parttimers verdienen immers doorgaans minder dan fulltimers). Aan de andere kant is de duur van de WW beperkt en krijgt daarna iedereen min of meer dezelfde bijstandsuitkering.
} 
stijgen met 25 miljoen euro (11.700 euro bruto-inkomen per werkloze), 28 miljoen euro, en 53 miljoen euro in scenario 1,2 en 3 respectievelijk. ${ }^{14}$ De afname in de vraag heeft ook een negatief effect op de opbrengsten uit de inkomstenbelasting voor bedrijven. Als we aannemen dat inkomstenbelastingen voor bedrijven gelijk zijn aan 0,5\% van de omzet in de groot- en detailhandel (CBS Statline) en de inkomstenbelastingen $1 \%$ van de omzet in de sierteelt (Wageningen Economic Research), zullen overheidsinkomsten met nog eens 3,7 miljoen euro dalen in scenario 1, 7 miljoen in scenario 2 en 10 miljoen in scenario 3.

De overheidsinkomsten zijn dan, dat in aanmerkend nemend, 159 en 73 miljoen euro in scenario 1 en 3. In scenario 2 is het totale effect negatief: -88 miljoen euro. Dat betekent dat de verhoging van de btw in andere landen via de daardoor veroorzaakte vraaguitval en terugloop van export en productie in Nederland, negatieve gevolgen heeft voor de belastinginkomsten en uitgaven aan sociale zekerheid in Nederland.

Tabel 5.8 Effecten op de inkomstenbelastingen en sociale premies in Nederland per scenario, in miljoen euro

\begin{tabular}{|c|c|c|c|}
\hline & Scenario 1 & Scenario 2 & Scenario 3 \\
\hline Banen op het spel, in aantal fte & 2.830 & 3.190 & 6.000 \\
\hline Primaire sector & 520 & 2.370 & 2.890 \\
\hline Detailhandel & 2.060 & -70 & 1.990 \\
\hline \multicolumn{4}{|l|}{ Gemiddeld salaris, in 1.000 euro, per fte } \\
\hline Groothandel & 52.600 & 52.600 & 52.600 \\
\hline Detailhandel & 29.200 & 29.200 & 29.200 \\
\hline Bruto inkomen van werkloze, in 1.000 euro & 11.700 & 11.700 & 11.700 \\
\hline Belasting \% & 24,5 & 24,5 & 24,5 \\
\hline Effect op belastinginkomsten overheid & -14 & -22 & -36 \\
\hline - Groothandel & 13.100 & 13.100 & 13.100 \\
\hline Detailhandel & 7.900 & 7.900 & 7.900 \\
\hline Effect op sociale premies & -24 & -33 & -57 \\
\hline Toename kosten sociale zekerheid & -25 & -28 & -53 \\
\hline Effect op inkomstenbelasting bedrijven & -4 & -7 & -10 \\
\hline Netto-effect op overheidsinkomsten en sociale premies & 159 & -88 & 73 \\
\hline
\end{tabular}

Bron: CBS, Hortus-model. Berekeningen Wageningen Economic Research.

Het is niet waarschijnlijk dat de daling van de inkomstenbelastingen op lange termijn voortduurt, omdat er op lange termijn werk en belastinginkomsten gegenereerd zullen worden in andere sectoren. 'Lange termijn' is in de economie een aanduiding voor de tijd die de economie nodig heeft om zich aan te passen aan veranderingen in bijvoorbeeld de belastingstructuur. De economische theorie geeft niet aan hoeveel tijd de economie nodig heeft om het nieuwe langetermijnevenwicht te realiseren. Op korte termijn stijgen de overheidsinkomsten met 159 en 73 miljoen euro in scenario 1 en 3 en op lange termijn met ongeveer bijna 230 miljoen euro in beide scenario's. In scenario 2 dalen de overheidsfinanciën met 88 miljoen op korte termijn en is het langetermijneffect beperkt.

Opgemerkt moet worden dat een deel van de extra overheidsinkomsten een herverdeling impliceert van lokale overheden naar de nationale overheid, omdat lokale overheden meer btw zullen moeten betalen voor de sierteeltproducten die zij aankopen voor openbaar groen.

\footnotetext{
${ }^{14}$ Het product van $75,5 \% * € 11.700 * 2.830$. NB. De $24,5 \%$ inkomstenbelasting is vestzak-broekzak.
} 
Dit onderzoek laat zien dat een verhoging van de btw op sierteeltproducten in Nederland en andere EU-landen in potentie grote effecten heeft op de omzet en werkgelegenheid. Er zijn drie scenario's doorgerekend:

1. een unilaterale verhoging van de btw op sierteeltproducten in Nederland, i.e. toepassing van het algemene tarief van $21 \%$ in plaats van het verlaagde tarief van $9 \%$;

2. een verhoging van de btw in de twaalf andere EU-lidstaten die momenteel het verlaagde tarief hanteren;

3. een verhoging van de btw in zowel Nederland als de andere twaalf EU-landen met een verlaagd tarief.

\section{Scenario 1}

De modelberekeningen laten zien dat in het eerste scenario in Nederland de detailhandelsomzet met 420 miljoen euro terugloopt (-13\%). De omzet van de primaire sector en de groothandel dalen met respectievelijk 80 miljoen euro $(-1,3 \%)$ en 170 miljoen euro $(-1,6 \%)$. Er gaan 2.830 voltijdsbanen $(-3,9 \%)$ in de Nederlandse sierteeltketen verloren als de btw op sierteeltproducten in Nederland van $9 \%$ naar $21 \%$ wordt verhoogd.

\section{Scenario 2}

Wanneer alleen in de twaalf andere EU-landen buiten Nederland het tarief wordt verhoogd, dan heeft dat alsnog gevolgen voor Nederland. Die gevolgen zijn dan vooral voelbaar in de Nederlandse primaire sector en groothandel, die een belangrijke rol spelen in de Europese sierteelt. In dat scenario is het omzetverlies in de primaire sector in Nederland 350 miljoen euro $(-6 \%)$ en in de groothandel 620 miljoen euro $(-6 \%)$ en het banenverlies in totaal 3.190 voltijdsbanen. In de hele EU-27 levert dit scenario een vraaguitval van 4,7 miljard euro op detailhandelsniveau op, en een daling van de omzet van de primaire sector en groothandel van respectievelijk 1,3 miljard euro (-7\%) en 2,8 miljard euro $(-7 \%)$. Het verlies aan werkgelegenheid in de EU en het Verenigd Koninkrijk bedraagt in totaal 53.700 voltijdsbanen.

\section{Scenario 3}

Als in alle EU-landen die momenteel een verlaagd tarief hanteren, inclusief Nederland, de btw wordt verhoogd, is het verwachte omzetverlies op detailhandelsniveau in de hele EU-27 en het Verenigd Koninkrijk samen ruim 5,1 miljard euro (-9\%). De omzet van de primaire productie daalt met 1,4 miljard euro $(-8 \%)$ en de omzet van de groothandel met 3 miljard euro $(-8 \%)$. Het effect op de werkgelegenheid is ingeschat op een verlies van bijna 57.400 voltijdsbanen.

In dit scenario zijn de effecten voor Nederland ook het grootst: 400 miljoen euro omzetverlies in de detailhandel $(-12 \%), 780$ miljoen euro $(-7 \%)$ op groothandelsniveau en 430 miljoen euro $(-7 \%)$ verlies in de primaire sector. In termen van werkgelegenheid zijn de effecten in scenario 3 berekend op 6.000 voltijdsbanen $(-9 \%)$ in de Nederlandse sierteeltketen, waarvan $2.890(-7 \%)$ in de primaire sector, $1.120(-7 \%)$ in de groothandel en $1.990(-15 \%)$ in de detailhandel.

\section{Effect op de overheidsfinanciën in Nederland}

Het effect op de overheidsfinanciën in Nederland van een btw-verhoging is ook bekeken. Daaruit blijkt de initiële inkomstenverhoging van een btw-stijging deels teniet wordt gedaan doordat de vraag naar sierteeltproducten afneemt, doordat banen verloren gaan en daardoor minder inkomstenbelasting wordt betaald en meer uitkeringen moeten worden betaald. Ook de afdrachten aan sociale premies zullen dalen. In scenario 1 blijft van een initieel verwachte opbrengst van 360 miljoen euro uiteindelijk 159 miljoen euro per jaar over op korte termijn, en 226 miljoen euro op langere termijn. In scenario 3 is dat 73 miljoen euro en 229 miljoen euro respectievelijk. De langetermijneffecten betekenen dat alle werknemers die een baan verloren hebben weer elders werk hebben gevonden en alle kapitaal die eerst in de sierteeltketen werd ingezet elders weer profijtelijk wordt aangewend. Het is niet op 
voorhand duidelijk hoe lang zo'n aanpassingsproces zal duren. In scenario 2 wordt de btw in Nederland niet verhoogd. Het effect op de btw-opbrengsten van de overheid is daarom vrijwel nihil. Er is wel sprake van vraaguitval in het buitenland en dat heeft een negatief effect op de keten in Nederland en op de overheidsinkomsten: -88 miljoen euro op de korte termijn door stijging van de werkloosheid en vermindering van de inkomsten uit belasting en sociale premies. 


\section{Literatuur en websites}

Bunte, F.H.J. and van Galen, M.A. (2019). The VAT directive for ornamental flowers and plants. Acta Hortic. 1242, 873-880. https://doi.org/10.17660/ActaHortic.2019.1242.128

Bunte, F.H.J. en M.A. van Galen (2005). Hortus; Modelling HORTicultural Use and Supply. The Hague, LEI, report 8.05.05.

Bunte, F.H.J. en M.A. van Galen (2015). Effecten van verhoging btw-tarief voor sierteeltproducten. Wageningen, LEI Wageningen UR, LEI, rapport 2015-103 - 25 p.

Bunte, F.H.J. en N. van der Poel (2010). Reduced VAT rates for flowers and plants. Den Haag, LEI, rapport 2010-069.

Bunte, F.H.J. en W.E. Kuiper (2008). Promoting Floriculture using VAT Regulation, European Journal of Horticultural Science 73(6): 248-253.

Bunte, F.H.J., J. van der Lugt en H. van der Meulen (2007). Beleidsevaluatie btw-regeling sierteeltproducten, Den Haag, LEI, rapport 6-07-22.

CPB (2003). Contra-expertise effecten btw-verlaging arbeidsintensieve diensten, Den Haag: CPB. 
Wageningen Economic Research Postbus 29703

2502 LS Den Haag

T 0703358330

Ecommunications.ssg@wur.nl

www.wur.nl/economic-research

Wageningen Economic Research RAPPORT

2021-043
De missie van Wageningen University \& Research is 'To explore the potential of nature to improve the quality of life'. Binnen Wageningen University \& Research bundelen Wageningen University en gespecialiseerde onderzoeksinstituten van Stichting Wageningen Research hun krachten om bij te dragen aan de oplossing van belangrijke vragen in het domein van gezonde voeding en leefomgeving. Met ongeveer 30 vestigingen, 6.500 medewerkers ( $5.500 \mathrm{fte})$ en 12.500 studenten behoort Wageningen University \& Research wereldwijd tot de aansprekende kennisinstellingen binnen haar domein. De integrale benadering van de vraagstukken en de samenwerking tussen verschillende disciplines vormen het hart van de unieke Wageningen aanpak. 



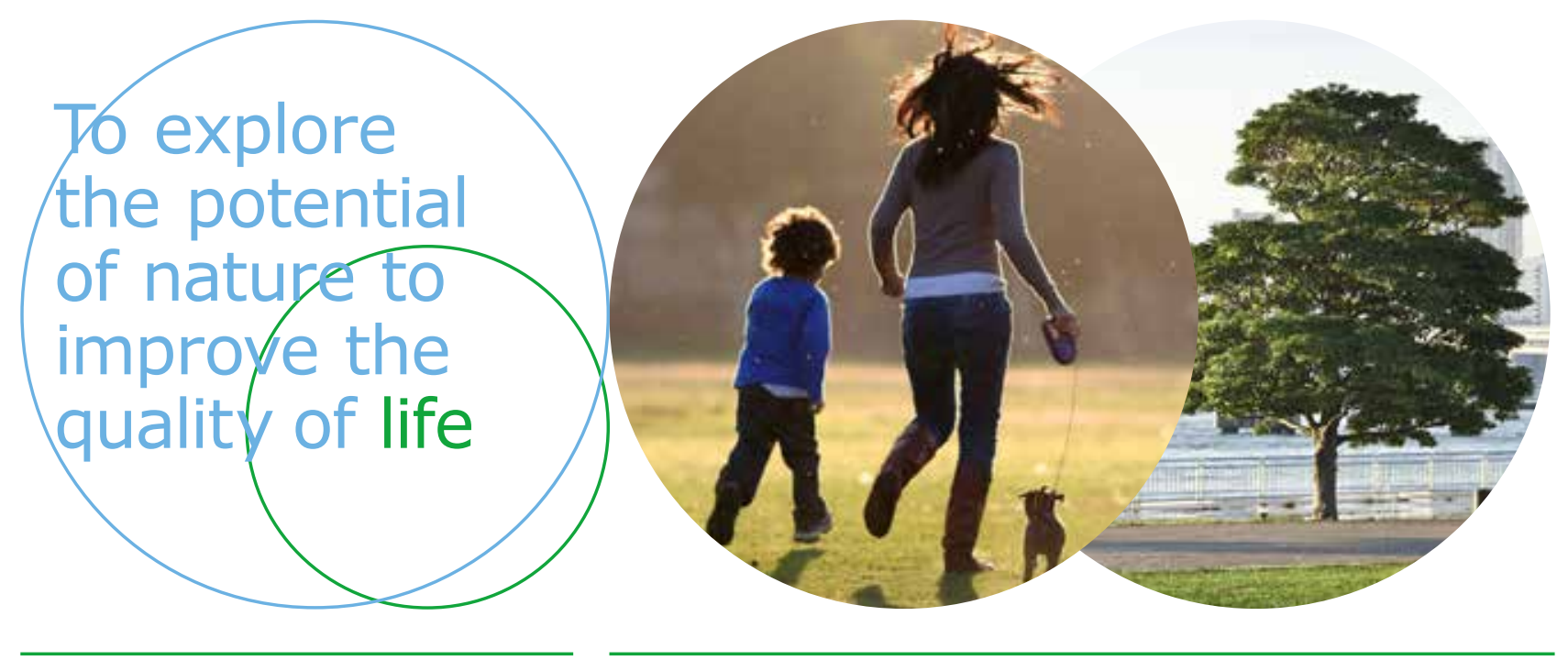

Wageningen Economic Research Postbus 29703

2502 LS Den Haag

T 0703358330

E communications.ssg@wur.nl www.wur.nl/economic-research

Rapport 2021-043

ISBN XXXX
De missie van Wageningen University \& Research is 'To explore the potential of nature to improve the quality of life'. Binnen Wageningen University \& Research bundelen Wageningen University en gespecialiseerde onderzoeksinstituten van Stichting Wageningen Research hun krachten om bij te dragen aan de oplossing van belangrijke vragen in het domein van gezonde voeding en leefomgeving. Met ongeveer 30 vestigingen, 6.500 medewerkers ( $5.500 \mathrm{fte}$ ) en 12.500 studenten behoort Wageningen University \& Research wereldwijd tot de aansprekende kennisinstellingen binnen haar domein. De integrale benadering van de vraagstukken en de samenwerking tussen verschillende disciplines vormen het hart van de unieke Wageningen aanpak. 